\title{
Retention of early pregnancy and its relationship to serum progesterone in dairy cattle
}

\author{
Melanie J. Starbuck \\ West Virginia University
}

Follow this and additional works at: https://researchrepository.wvu.edu/etd

\section{Recommended Citation}

Starbuck, Melanie J., "Retention of early pregnancy and its relationship to serum progesterone in dairy cattle" (2002). Graduate Theses, Dissertations, and Problem Reports. 1502.

https://researchrepository.wvu.edu/etd/1502

This Thesis is protected by copyright and/or related rights. It has been brought to you by the The Research Repository @ WVU with permission from the rights-holder(s). You are free to use this Thesis in any way that is permitted by the copyright and related rights legislation that applies to your use. For other uses you must obtain permission from the rights-holder(s) directly, unless additional rights are indicated by a Creative Commons license in the record and/ or on the work itself. This Thesis has been accepted for inclusion in WVU Graduate Theses, Dissertations, and Problem Reports collection by an authorized administrator of The Research Repository @ WVU. For more information, please contact researchrepository@mail.wvu.edu. 


\title{
RETENTION OF EARLY PREGNANCY AND ITS RELATIONSHIP TO SERUM PROGESTERONE IN DAIRY CATTLE
}

\author{
Melanie J. Starbuck \\ Thesis submitted to the \\ Davis College of Agriculture, Forestry and Consumer Sciences \\ at West Virginia University \\ in partial fulfillment of the requirements \\ for the degree of \\ Master of Science \\ in \\ Reproductive Physiology \\ E. Keith Inskeep, Ph.D., Chair \\ Paul E. Lewis, Ph.D. \\ Robert A. Dailey, Ph.D. \\ Faculty of Reproductive Physiology \\ Morgantown, West Virginia \\ 2002
}

Keywords: Embryo mortality, Progesterone, Dairy cattle 


\begin{abstract}
Retention of early pregnancy and its relationship to serum progesterone in dairy cattle

\author{
Melanie. J. Starbuck
}

Factors affecting pregnancy maintenance between 28 and 67 days of gestation were studied in dairy cows $(N=211)$. Beginning on day 28 to 37 post breeding, cows were examined by ultrasonography for a viable pregnancy. Pregnant cows were reexamined for pregnancy losses during the late embryonic (< day 45$)$ and early fetal stages up to day 67 . Overall pregnancy loss was $11 \%$, mostly occurring before day 45 . Cows with two corpora lutea maintained fewer pregnancies than cows with one corpus luteum. Pregnancy retention was less when concentrations of progesterone were low during days 28 to 37 . The embryo apparently died before luteal regression. Pregnancy retention declined as body condition and age of the cow increased. Pregnancy retention between days 28 and 67 of pregnancy was associated with luteal function during $\mathrm{d} 28$ to 37 .
\end{abstract}




\section{TABLE OF CONTENTS}

ABSTRACT.

.ii

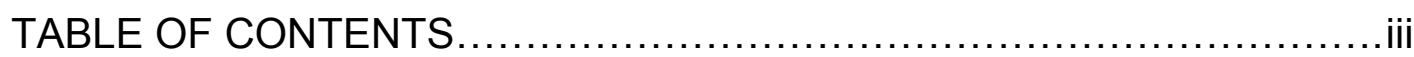

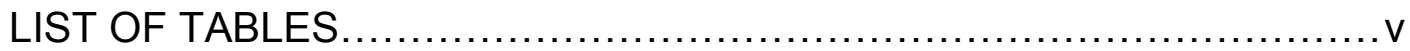

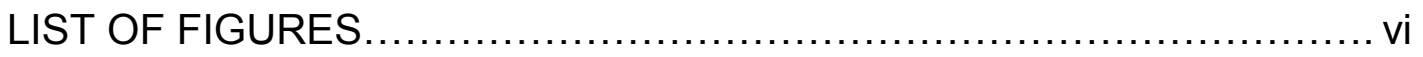

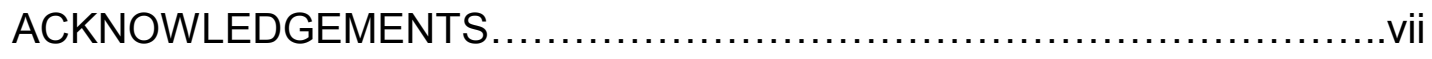

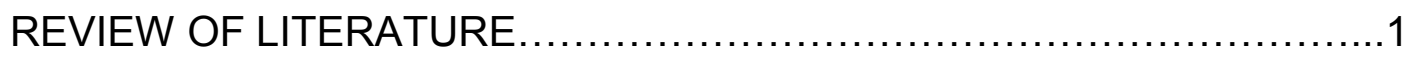

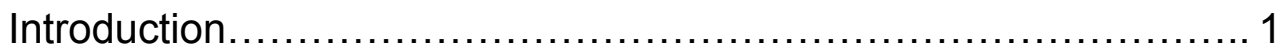

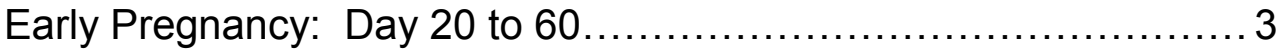

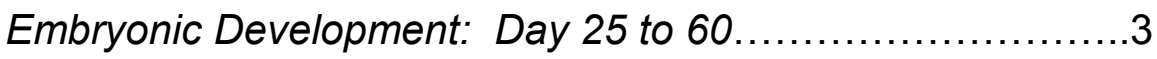

Implantation and Placentation: Day 20 to $42 \ldots \ldots \ldots \ldots \ldots \ldots . . . . . .4$

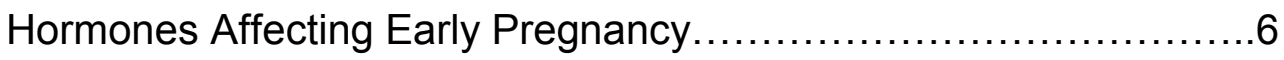

Progesterone.................................................... 6

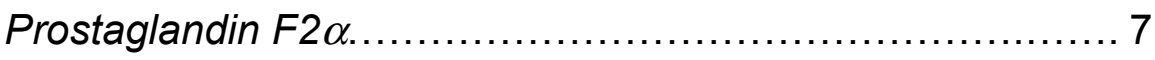

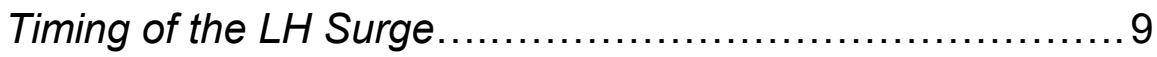

Multiple Offspring and Pregnancy Loss............................. 11

Effect of Heat Stress on Embryonic Survival.........................13

Secretions by the Embryo and Fetus............................... 14

Genetic Abnormalities........................................... 17

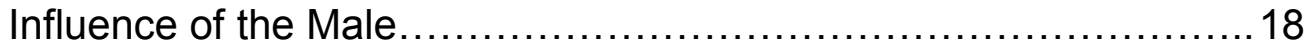

Infectious Abortion and Embryonic Mortality........................ 19

Bovine Virus Diarrhea Virus.................................... 19

Infectious Bovine Rhinotracheitis............................ 21 
Actinomyces pyogenes...................................... 21

Other Diseases............................................. 21

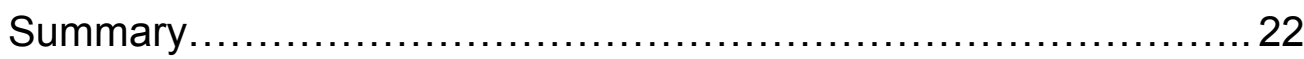

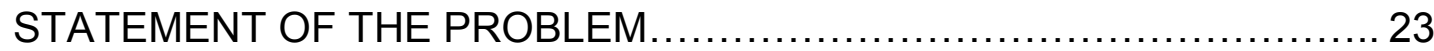

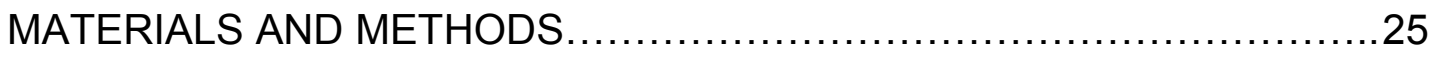

Animals and Synchronization of Estrus ..............................25

Determination of Pregnancy Loss................................. 25

Blood Collection and Radioimmunoassays.......................... 26

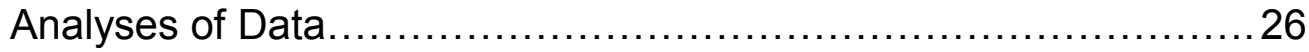

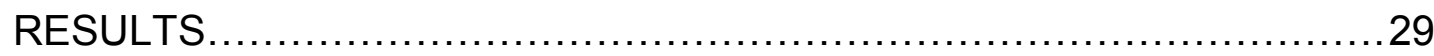

Timing of Embryonic/Fetal Mortality................................29

Number of Corpora Lutea.........................................29

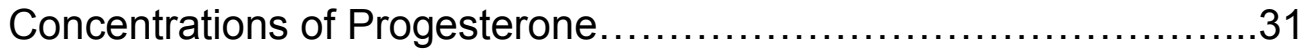

Cow Characteristics and Other Factors............................ 34

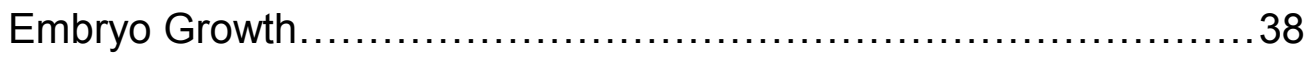

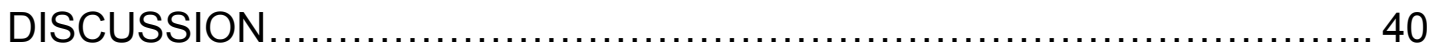

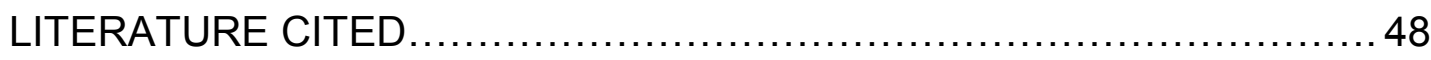

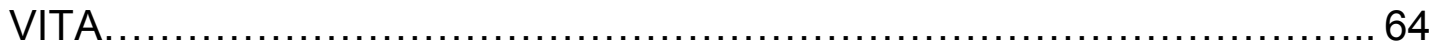




\section{LIST OF TABLES}

Table 1. Concentrations of progesterone in cows with one or two corpora lutea

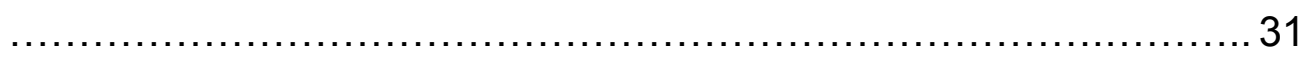

Table 2. Effect of concentrations of progesterone at two stages of gestation on

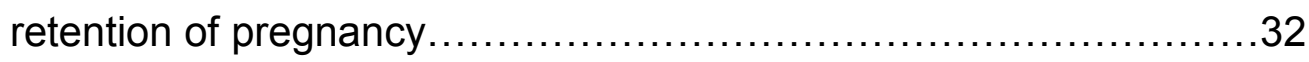




\section{LIST OF FIGURES}

Figure 1. Effect of number of corpora lutea on pregnancy retention to 58 to 67

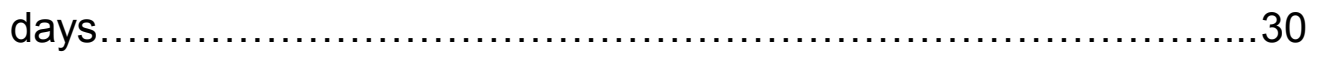

Figure 2. Patterns of concentrations of progesterone for five animals from Farm

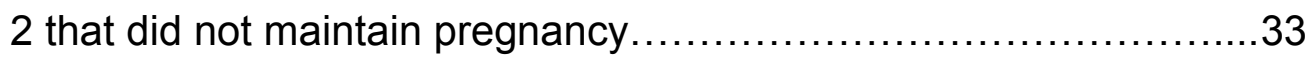

Figure 3. Effect of body condition score on pregnancy retention..............35

Figure 4. Effect of age on pregnancy retention............................36

Figure 5. A. Variation among the four most frequently used sires in pregnancy retention. B. Variation among the four most frequently used sires in pregnancy

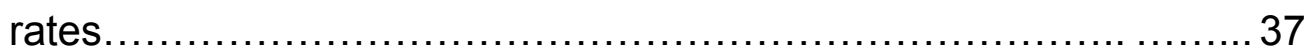

Figure 6 . Average sizes of embryos between days 28 and 61 of gestation as determined from ultrasonography of 70 animals. 


\section{AKNOWLEDGEMENTS}

My utmost appreciation goes first to my family, who always supported me even though they did not understand what I was doing, despite being perplexed when I left my interest in sheep behind. They raised me to have a strong work ethic and to be independent, which were both essential in completing this project.

Second, I would like to thank the faculty on my committee. Thanks go to Dr. Inskeep for his guidance, sharp proofreading eye and for enduring one cold winter day of cow work in my absence. I am just now starting to get the hang of things. Dr. Lewis accompanied me many times on trips to Eglon, but perhaps most importantly taught me that there is more to life than work. Finally, thanks go to Dr. Dailey for his keen point of view and his attempts to show me that I really do know more than I think.

I would like to thank those at the Bachtel Dairy; Carl, Mark, Alan and Ronnie, for their cooperation, interest and assistance with this project, even though much of that assistance was related to vehicles. I would like to thank the farm crew at the WVU dairy, Will, Jimmy, Greg and Gary, for their assistance in retrieving unruly cows and for being patient with me because I did things out of routine. My gratitude is extended to those who took time from their schedules to be my traveling assistant and extension cord overseer, Quinn Baptiste, Beth Costine, Jason Candler, Alison Dixon, Ida Holoskova, Mike Kaller, Nancy Kerr and TD Maze. My fellow graduate students and other friends made this an enjoyable experience and I think we can all agree that we have learned something along the way. 


\section{REVIEW OF LITERATURE}

\section{Introduction}

To a single breeding, fertilization rates of 82 to $100 \%$ can be expected for beef heifers (Diskin and Sreenan, 1980; Maurer and Chenault, 1983). Fertilization rates of $100 \%$ have been reported for parous beef females following natural service (Maurer and Chenault, 1983), while those for parous dairy cattle inseminated artificially with fresh semen were $85 \%$ to $89 \%$ (Kidder et al., 1954; Boyd et al., 1969). Calving rates to a single insemination are 52 to $57 \%$ in dairy cattle (Mawhinney and Roche, 1978) and approximately $55 \%$ in beef cattle (Diskin and Sreenan, 1980). In genitally-normal beef heifers, fertilization failure accounted for about $10 \%$ and embryonic death accounted for approximately $30 \%$ of overall reproductive failure (Diskin and Sreenan, 1980). Embryonic mortality occurs after conception and before differentiation of the embryo into a fetus, around day 45 in cattle (Winters et al., 1942).

Causes of embryonic mortality can be classified under two broad categories, environmental factors and genetic factors (Ayalon, 1978; King, 1991; Kastelic, 1994). Environmental factors can be divided between internal and external factors. The internal environment is perhaps the most studied, including physiology of the uterine environment, the hormones secreted by the dam to maintain pregnancy or enhance embryonic development, and the hormones secreted by the embryo. The roles of nutrition, disease, temperature or other environmental stressors would be classified as external factors, all of which may affect embryonic survival. King (1991) reviewed embryonic mortality from the point of view of the embryo, while most research centers on the maternal role in pregnancy maintenance. 
When the majority of embryonic mortality occurs is yet to be distinguished, because there is no reliable early indicator available without terminating the pregnancy, which makes it difficult to pinpoint an acceptably small time period to research intensively. If death or removal of the embryo occurs before day 15 in the cow (Northey and French, 1980) or day 12 in the ewe (Moor and Rowson, 1966), length of the estrous cycle is unaffected. Presence of an embryo after these times, even though it may die shortly thereafter, extends the estrous cycle, as maternal recognition of pregnancy has already begun. The majority of embryonic loss in cattle occurs without notice, and it may appear as though the animal did not conceive and is cycling normally. For parous beef females slaughtered at intervals up to day 16, Maurer and Chenault (1983) reported that $67 \%$ of embryonic mortality to that time had occurred by day 8 . In beef heifers, the majority of embryonic loss occurred by day 16 (Diskin and Sreenan, 1980) or as early as day 14 (Dunne et al., 2000). Reproductive failure in beef heifers has been attributed to both fertilization failure and embryonic mortality occurring before day 8 , while failure to maintain pregnancy in parous cows has been attributed solely to embryonic mortality (Maurer and Chenault, 1983). Ayalon (1978) made the opposite conclusions with dairy cattle, that embryonic mortality was the primary cause of reproductive failure in heifers and that reproductive failure in cows was distributed evenly between fertilization failure and embryonic mortality. Despite these opposing reports, it can be concluded that even in cases in which fertilization is near $100 \%$, some embryonic mortality is likely to occur. In fact, Saacke et al. (2000) have pointed out that the optimal time of breeding for maximum fertilization rate is later than the optimum time for maximal embryonic survival. 
Late embryonic mortality, after maternal recognition of pregnancy, also has been recorded. Estimates of $7 \%$ and $12 \%$ embryonic loss between days 24 and 75 of pregnancy were reported for dairy cattle, determined by concentrations of milk progesterone (Kummerfield et al., 1978; Bulman and Lamming, 1979). More recent data in dairy cattle, especially those being synchronized for timed artificial insemination, present significant amounts of late embryonic mortality. Data have been collected for day 28 , shortly after the embryo is visible by ultrasonography, to day 42 or later, when pregnancy is diagnosed easily by palpation. Estimates of embryo loss ranged from $13.3 \%$ (Cartmill et al., 2000) to $45.9 \%$ (El Zarkouny et al., 2000) for lactating dairy cows in which estrus was synchronized with the OvSynch protocol (Pursley et al., 1995) and timed insemination was used. When studies performed at multiple locations were compared regardless of synchronization treatment or cycling status, loss rates of approximately 15 to $30 \%$ were common in timed-inseminated lactating dairy cows (Inskeep, 2002).

\section{Early Pregnancy: Day 20 to 60}

Embryonic Development: Day 25 to 60 . By day 25 of gestation, the bovine embryo weighs approximately $0.15 \mathrm{~g}$ (Eley et al., 1978) and appears as a 'C' shape, which is approximately $6 \mathrm{~mm}$ in length (Curran et al., 1986). By this time the heartbeat and allantois are visible by ultrasonographic examination. The heart rate decreases between days 20 and 26, then remains constant until day 60 (Kastelic et al., 1988). The allantois appears as an echogenic circle with attachment to the midventral portion of the embryo, but contains $<4 \mathrm{ml}$ of fluid until approximately day 40 (Eley, 1979). By day 30 of gestation, the forelimb and hind limb buds, spinal cord and amnion are visible and the 
embryo begins to take on an 'L' shape (Curran et al., 1986), despite weighing $<1 \mathrm{~g}$ (Eley, 1979). Placentomes are visible as smooth, semicircular elevations by day 35 and are first detected only near the embryo proper, but spread throughout the gravid horn by day 60 (Kastelic et al., 1988). Between days 40 and 60 the embryo becomes a fetus as organs develop. Size increases from $1 \mathrm{~g}$ to $14 \mathrm{~g}$ during this time (Eley et al., 1979) and the conceptus exhibits quadratic growth from day 20 to 60 (Curran et al., 1986).

Implantation and Placentation: Days 20 to 42 . A developing embryo is dependent on uterine gland secretions diffusing through unattached membranes until placental attachment occurs. Establishment of a functional placenta for transfer of nutrients and waste involves apposition and adhesion between the trophoblast and uterine surfaces in a gradual process. By day 15, a serosal vesicle lined with endoderm fills the cavity of the pregnant uterine horn (Marion and Gier, 1958). Villous regions that develop on this vesicle, called cotyledons, will attach to caruncles in the uterine endometrium, creating placentomes and making direct transfer of nutrients to the developing extra-embryonic circulation possible. The cotyledonary attachment is characteristic of ruminants, and the bovine placenta is referred to as syndesmochorial (Chang, 1952).

Placental development is a progressive process. A layer of epithelial cells covers caruncular tissue in the non-pregnant cow; this layer is lost as the first response of the caruncles to the embryonic membrane (Melton et al., 1951). Maternal caruncular epithelium is variable at 20 days of gestation, but by day 27 the epithelial cells become more regular and cuboidal in shape as the epithelium changes from smooth to undulated (King et al., 1980). Attachment begins near the embryo with the proliferation 
of trophoblastic cells, forming cotyledons on the chorionic membrane over the caruncular areas. This process begins by day 30 and has spread to the body of the gravid uterine horn by day 35 and to the contralateral horn by day 38 (Melton et al., 1951). Where caruncular and cotyledonary tissue meet, creating a placentome, villi and crypts will begin to form. At 33 days of gestation, the villi are not branched and range from 120 to $520 \mu \mathrm{m}$ in length. Within three days they become branched, increasing contact, and by 42 days are approximately $1200 \mu \mathrm{m}$ in length. Few structural changes in the placentomes take place after 42 days (King et al., 1979).

The intercaruncular tissue undergoes villi-like modification, which functions to increase respiratory capacity and to transport larger or less diffusible molecules.

Contact in the intercaruncular areas is not as great as in caruncular areas and appears to be similar to the diffuse placenta of the pig and horse. The greatest areas of contact with the intercaruncular tissue are in the middle section of each uterine horn (King and Atkinson, 1987).

The presence, distribution and size of lipid droplets within the cells of both the embryonic and maternal epithelium undergo dramatic changes between days 20 and 42. By day 29 , extensive accumulation of lipid droplets is observed, concentrated in the basal region of the mononuclear cells (King et al., 1980). Single, medium to large lipid droplets are located in the binucleated giant cells; however, these lipid droplets are sparse in areas heavily populated with binucleated giant cells. Binucleated giant cells originate from the trophoblastic cells, and then migrate from the chorionic epithelium to invade the maternal endometrial epithelium where they secrete placental lactogen and pregnancy specific protein B. Other droplets at this time appeared as dense clumps of 
smaller droplets. By day 33, the lipid concentration and size of droplets present in the fetal giant cells have decreased (King et al., 1979). These lipid droplets may be used as substrates for the synthesis of prostaglandins, which are important for implantation in species like the rodent (Evans and Kennedy, 1978). Prostaglandins and their role(s) in pregnancy will be discussed later.

\section{Hormones Affecting Early Pregnancy}

Progesterone. Concentrations of progesterone in pregnant animals have been reported to increase over those in open animals beginning as early as day 3 to 6 (Maurer and Echternkamp, 1982; Albihn, 1991). Concentrations of blood progesterone were decreased by poor nutrition and weight loss (Beal et al., 1978; Gombe and Hansel, 1973). Metabolism of progesterone can be affected by diet and grazing time (Rabiee, 2000). High producing cows in early lactation have a higher rate of metabolism than low producing cows (Huntington, 1990; Butler, 2000). The level of nutrition did not alter the concentration of progesterone in either luteal tissue or ovarian venous blood of ewes (Abecia et al., 1995, 1997) or cows (Apgar et al., 1975); therefore, variation in peripheral blood progesterone is most likely caused by differences in metabolism.

Prevention of luteal regression is essential for continued pregnancy beyond the duration of the estrous cycle, a process known as maternal recognition of pregnancy. Kastelic (1991) reported that luteal regression occurred prior to embryo death when embryonic mortality took place before day 25 of gestation and embryo death preceded luteal regression when embryonic mortality occurred between days 25 and 40 of gestation. Experimentally-induced luteal regression on day 28 or 42 of pregnancy 
resulted in quick embryonic death (2.4 days), which was followed shortly (2.6 days later) by ovulation. In the same study, embryonic death was caused abruptly, by rupture of the amniotic vesicle, or slowly, by colchicine injection, on day 42 of gestation. Neither of these treatments resulted in luteal regression until just before ovulation, 35 and 22 days after embryonic death (Kastelic, 1989).

Supplementation with progesterone around the time of maternal recognition of pregnancy may increase pregnancy rates, if overall herd fertility is low. Diskin and Niswender (1989) reported no improvement of embryonic survival in ewes treated with progesterone from day 7 to 50 of gestation when compared to control ewes. Variable results have been reported when cows were treated with hCG (Morris et al., 1976; Lewis et al., 1990) or GnRH (Rettmer et al., 1992; Stevenson et al., 1993). Direct effects of progesterone on late embryonic survival have not been reported, however, treatment with progesterone early in the estrous cycle can affect embryo growth. Day14 embryos from cows treated with progesterone on days 1 through 4 of pregnancy were more advanced than embryos from control animals and uterine endometrial secretions were altered by day 5 (Garrett et al., 1988). Embryos from ewes with short, regular estrous cycles had greater luteotropic capabilities on day 13 than embryos from ewes with estrous cycles of typical length as indicated by the fact that concentrations of progesterone increased more quickly (Nephew et al., 1991). Pregnant cows with embryos that did not produce detectable concentrations of interferon $\tau(\mathrm{IFN}-\tau)$ at day 16 had similar estrogen profiles but slower rises in progesterone than those with embryos that produced detectable concentrations of IFN- $\tau$ (Mann and Lamming, 2001).

Prostaglandin $F_{2 \alpha}\left(P G F_{2 \alpha}\right)$. The effect of prostaglandins on embryo quality and 
viability has been studied most in the early postpartum cow. Greater concentrations of 15-keto, 13,14-dihydro-PGF ${ }_{2 \alpha}$ (PGFM), the primary metabolite of PGF $_{2 \alpha}$ were found in circulation in early postpartum ( 0 to 36 days) dairy cows that developed endometritis than in those that did not (Seals et al., 2002). Premature increases in secretion of $\mathrm{PGF}_{2 \alpha}$ have been associated with the first postpartum ovulation and lead to a shortened cycle (Ramirez-Godinez et al., 1981; Cooper et al., 1991). Even when an exogenous progestagen was provided to replace the regressing $\mathrm{CL}$, cows bred at first postpartum ovulation failed to maintain pregnancy (Breuel et al, 1993). When day-6 embryos from cows with short luteal phases were transferred into cows with normal cycles, pregnancy could be maintained (Schrick et al., 1993). When good quality embryos from cows with normal cycles were transferred into cows with short cycles given supplemental progesterone, pregnancy rates were half those following transfer of good quality embryos into cows with normal cycles; therefore, Butcher et al. (1992) suggested that the altered environment within the uterus may be hostile to embryonic survival. Schrick et al. (1993) reported greater concentrations of $\mathrm{PGF}_{2 \alpha}$ in the uterine lumen of cows with short cycles than in cows with normal cycles. Cows with greater concentrations of PGF $_{2 \alpha}$ had lower quality embryos (Schrick et al., 1993; Hockett et al., 1998). Increased uterine $\mathrm{PGF}_{2 \alpha}$ has been reported in cows with negative energy balances (Butler et al., 1998), experimentally-induced mastitis (Hockett et al., 2000) and heat stress (Malayer et al., 1990) that may lead to increased embryonic death.

In contrast to the reports of decreased early embryonic viability with increased secretion of uterine $\mathrm{PGF}_{2 \alpha}$, Bridges et al. (2000) examined $\mathrm{PGF}_{2 \alpha}$ during later embryonic development. Pregnancy retention was greater in cows dependent upon an 
hCG-induced replacement $\mathrm{CL}$ if they had greater concentrations of $\mathrm{PGF}_{2 \alpha}$ in plasma from the inferior vena cava during days 31 to 36 of gestation. Higher concentrations of $\mathrm{PGF}_{2 \alpha}$ may be important in the implantation process. In the rat, implantation begins on day 5 of gestation, when uterine activity of phospholipase $A_{2}, \mathrm{PGF}_{2 \alpha}$ and PGE were increased (Novaro et al., 1996). Treatment with indomethacin on day 5 of pregnancy in the rat caused decreased weight of implantation sites and extended the length of pregnancy (Kennedy et al., 1977). Similar results were reported in the hamster, as indomethacin decreased the weight of implantation sites and the associated increase in PGE (Evans and Kennedy, 1978). In the mouse, indomethacin blocked the decidual cell reaction and the associated increase in $\mathrm{PGF}_{2 \alpha}$ (Rankin et al., 1979). Prostaglandins are important in mediation of implantation in rodents. A role of $\mathrm{PGF}_{2 \alpha}$ in the adhesion and attachment process of implantation in the cow could explain why increased $\mathrm{PGF}_{2 \alpha}$ at days 31 to 36 of gestation is advantageous to pregnancy maintenance.

Timing of the LH Surge. Following ovulation, fertilization and very early embryonic development occur in the oviduct. Among the many factors that may influence embryonic development are secretions of the oviduct, which are controlled by steroid hormones (Gandolfi, 1994). Aberrations from the normal timing of hormonal events near ovulation and estrus may lead to changes that affect oocyte quality, resulting in decreased embryo survival.

Soede et al. (1994) reported that embryonic survival (the number of corpora lutea represented by viable embryos) to day 35 in sows was correlated negatively with the interval between peak concentrations of estradiol and LH or between peak estradiol and the subsequent rise of progesterone. The relationship was believed to be due to 
changes in the oviductal environment. Secretory activity of the oviduct was decreased in superovulated (eCG followed 48 hours later by $\mathrm{PGF}_{2 \alpha}$ ) dairy heifers in which the $\mathrm{LH}$ surge was postponed by norgestomet treatment, then induced with $\mathrm{GnRH}$. This treatment decreased embryo viability, without affecting blastocyst formation, cleavage rates or fertilization rates (van de Leemput et al., 2001). Although Lucy and Stevenson (1986) were looking at effects of $\mathrm{GnRH}$ treatment at estrus and subsequent changes in hormonal patterns, they reported data similar to those of Soede et al. (1994). Increased conception rates in dairy cows and heifers were associated with a shorter interval between peak concentrations of estradiol and $\mathrm{LH}$.

Delayed ovulation, whether naturally-occurring or artificially-induced, resulted in intrafollicular aging of the oocyte and an increased incidence of embryonic anomalies in the rat (Fugo et al., 1966; Fugo and Butcher, 1971; Butcher et al., 1967, Page et al., 1983). Morphological and chromosomal defects were increased, while fertilization and implantation rates were decreased when ovulation was delayed 48 hours with injection of sodium pentobarbital in rats (Butcher and Fugo, 1967). As determined by reciprocal transfer of embryos from delayed and normal rats, delayed ovulation and altered uterine environment decreased the implantation rate and changes in the oocyte led to increased incidence of embryonic abnormalities and mortality (Butcher et al., 1969). These changes are most likely due to an increase in the time of exposure of the oocyte to elevated concentrations of estradiol before ovulation (Butcher and Pope, 1979). Similar results, decreased fertilization and embryo development, have been reported in sheep when LH pulsatility was inhibited prior to ovulation with a $\mathrm{GnRH}$ antagonist (anterilix; Oussaid et al., 1999). 


\section{Multiple Offspring and Pregnancy Loss}

Twinning in cattle increases the rate of late embryonic and(or) fetal mortality. Echternkamp and Gregory (1999) reported that beef cows pregnant with twins had a loss rate of $12.4 \%$ compared to $3.5 \%$ for those with single offspring between pregnancy diagnosis by ultrasonography and parturition. An estimated $38 \%$ of twin pregnancies terminated in either observable abortion (21\%) or stillbirths (17\%; Erb and Morrison, 1959). Mortality of twin embryos usually occurs prior to day 35 (Anderson, 1982), however, earlier work by Anderson et al. (1978) reported fetal loss of twin pregnancies between days 45 and 60 of gestation at a rate of $27.8 \%$.

Unlike the sheep, litter bearing species, and the horse, partial losses of pregnancies rarely occur in the cow as death of one fetus in a twin pregnancy usually results in death of the other due to anastomosis of the placentas (Eckternkamp, 1992). The horse, also primarily a monovulatory species, is probably the best animal to compare to the cow, despite having a diffuse placental attachment. Twinning accounts for 10 to $30 \%$ of abortions in mares (Roberts, 1986), and it is rare when live twin foals are born and thrive. Embryonic fixation, when the embryo contacts directly with the endometrium, occurs on day 16 to 17 of gestation in the mare. Seventy percent of twins' vesicles fix unilaterally, in the same horn. Interestingly, $85 \%$ of unilaterally-fixed twin pregnancies undergo natural reduction by day 40 , however, bilaterally-fixed twin pregnancies do not. Embryos are implanted prior to natural reduction, which usually occurs between days 17 and 38 (Ginther and Pierson, 1984). How and why one embryo is selected for natural reduction is not well understood, although the close proximity of multiple embryos favors reduction from a twin pregnancy to a single 
pregnancy. Especially in unilateral twins, there is a loss of contact between the endometrial and trophoblastic surfaces from each embryo and in some cases the larger embryonic vesicle has been shown to partially surround the smaller one. Unilateral twins also undergo reduction earlier than bilateral twins, when the yolk sac, a less efficient distributor of nutrients, is still the predominant placenta (Ginther, 1984). As stated above, natural reduction of twin embryos rarely occurs in the cow.

What causes twinning in cattle? Cattle selected for twinning have significantly greater populations of secondary follicles, but an equal number of primary and primordial follicles (Cushman, 2000). Ultimately these cows are able to keep more follicles growing into the next stage. Fricke and Wiltbank (1999) reported that high producing dairy cows had significantly more ovulations than those of average and low production. This work supported the findings of Kinsel et al. (1998), in which the percentage of high milk producing cows with double ovulations was $20.2 \%$ compared to $6.9 \%$ for low producing cows $(\leq 40 \mathrm{~kg} / \mathrm{d})$. Lactating cows exposed to heat stress for the entire estrous cycle had greater populations of large $(>10 \mathrm{~mm})$ follicles during the first follicular wave (Wolfenson et al., 1985; Roth, 1998), and reduced dominance of the largest follicle, allowing the growth of a second large follicle and increasing the likelihood of multiple ovulations. Synchronization of estrus in cows during the first follicular wave of the cycle may result in the ovulation of more than one oocyte, as more co-dominant follicles developed during the first wave of the estrous cycle (Ginther et al., 2001). Monozygotic twins, resulting from division of a single fertilized oocyte occurred at a rate of 6.0 to $10.8 \%$ of all twin births (Johansson, 1932; Joubert, 1952). 


\section{Effects of Heat Stress on Embryonic Survival}

The effect of heat stress on reproduction is well documented and was the topic of a recent review by Wolfenson et al. (2000). Conception rates may decline from averages of 40 to $60 \%$ in cooler months to only 10 to $20 \%$ during times of high temperature and humidity (Cavestany et al., 1985). Conception rates in beef heifers exposed for 72 hours to elevated temperature $\left(32^{\circ} \mathrm{C}\right)$ or ideal temperature $\left(21^{\circ} \mathrm{C}\right)$ immediately following breeding were $0 \%$ and $48 \%$ respectively (Dunlap and Vincent, 1971). Exacerbating the problem of low fertility is the shortened duration and intensity of estrus during summer months (Bianca, 1985).

Under heat stress, the dominance of the first wave follicle may be reduced (Wolfenson et al., 1995) allowing the preovulatory follicle to emerge two to three days sooner than the preovulatory follicle of a non-heat stressed cow. The earlier emergence of the preovulatory follicle may result in an older follicle being ovulated, decreasing fertility (Mihm et al., 1994).

Heat stress during early pregnancy can affect later embryonic survival. Viability of unfertilized, ovulated ova from ewes that were heat stressed at mating was not different from control animals when transferred into a non-heat stressed mated ewe (Woody and Ulberg, 1964). However, when ewes were exposed to heat stress from mating to day 4 of gestation, embryonic survival was decreased, most likely due to alteration in the uterine environment (Alliston and Ulberg, 1961). Similar results were seen in superovulated, dairy heifers exposed to heat stress from ovulation to embryo collection (day 7; Putney et al., 1988a). Heat stress could alter spermatozoa in the female tract resulting in decreased embryonic survival (Bishop, 1964; Howarth et al., 
1965). Day-17 conceptuses cultured in vitro under heat stress showed increased induction of heat shock proteins, decreased production ( $72 \%$ that of controls) of interferon- $\tau$ (IFN- $\tau)$, a major secretory product of the conceptus between days 15 and 24 (Bartol et al., 1985), and increased secretion of prostaglandin E2. Under the same treatment, endometrial tissue secreted more prostaglandin F2 $\alpha$ in response to heat stress (Putney et al., 1988b). Low rates of continued pregnancy in response to heat stress may be caused by an alteration of the signals for maternal recognition of pregnancy from slow growing or poor quality embryos.

Heat stress that occurred between days 8 and 16 after insemination, when the blastocyst is growing rapidly, caused reduced conceptus weights and lower pregnancy rates in heifers (Biggers et al., 1987). It is well known that ewes bred out-of-season, exposed to high heat later in gestation, give birth to smaller lambs than those gestated over the winter (Yeates, 1956; Shelton and Morrow, 1965). Direct correlations between heat stress and late embryonic and early fetal mortality are difficult to establish because of the many systems that may be altered in response to heat stress.

\section{Secretions by the Embryo and Fetus}

Secretion of progesterone from the $\mathrm{CL}$ is essential for pregnancy maintenance in the cow. $\mathrm{PGF}_{2 \alpha}$ from the uterine endometrium initiates regression of the $\mathrm{CL}$ in absence of pregnancy. Presence of an embryo must attenuate secretion of $\mathrm{PGF}_{2 \alpha}$ or decrease the action of $\mathrm{PGF}_{2 \alpha}$. Presence of a viable embryo reportedly abolished episodic secretion of PGFM (Kindahl et al., 1976; Betteridge et al., 1984) and overcame the luteolytic effect of $\mathrm{PGF}_{2 \alpha}$ injected into the largest follicle on day 13 of pregnancy in the ewe (Pratt et al., 1977). Secretion of PGFM in response to oxytocin challenge was 
decreased during early pregnancy when compared with cyclic cows (Lafrance and Goff, 1985) and in pregnant ewes on days 14 to 15 of gestation (Silvia et al., 1992).

Endometrium from a day-17 pregnant uterus produced less PGF $_{2 \alpha}$ than endometrium from a day-17 cyclic cow in vitro (Gross et al., 1988). The conceptus produces a wide array of proteins that, when infused into the uterus of a cyclic cow (day 17), increased the interestrous interval and decreased secretion of $\mathrm{PGF}_{2 \alpha}$ (Knickerbocker, 1986). Silva et al. (2000) reported that the day-13 ovine corpus luteum of pregnancy has greater enzymatic activity of the enzyme prostaglandin dehydrogenase (PGDH), which converts $\mathrm{PGF}_{2 \alpha}$ to the inactive metabolite PGFM, than a corpus luteum from day 13 of the cycle, which may allow the corpus luteum of pregnancy to be more resistant to $\mathrm{PGF}_{2 \alpha}$.

IFN- $\tau$ mRNA is first present on day 12 and produced maximally on days 15 and 16, while IFN- $\tau$ is not detected in uterine flushings until days 14 to 16 (Farin et al., 1990). Production increases as the conceptus undergoes morphological change from spherical to filamentous (Farin et al., 1990). Production of IFN- $\tau$ has been correlated with concentrations of progesterone (Kerbler et al., 1997; Mann et al., 1999). Cows with slower post-ovulatory increases in progesterone and lower luteal phase concentrations of progesterone had day-16 embryos that exhibited no elongation and produced very little to no IFN- $\tau$ (Mann et al., 1999; Mann and Lamming, 2001). Multiple IFN- $\tau$ genes exist in cattle, two of which (IFN- $\tau 1 \mathrm{c}$ and IFN- $\tau 3 a$ ) are expressed more abundantly than others during the blastocyst stage (Ealy et al., 2001). The importance of how many genes for IFN- $\tau$ are expressed and when they are expressed remains an area of future study. Demmers et al. (2001) recently reviewed the action of IFN- $\tau$. IFN- $\tau$ inhibits endometrial expression of oxytocin receptors, through which oxytocin can stimulate 
secretion of $\mathrm{PGF}_{2 \alpha}$ in the non-pregnant animal. The decreased secretion of $\mathrm{PGF}_{2 \alpha}$ may be due also to direct inhibition of IFN- $\tau$ on expression of COX-2 mRNA (Pru et al., 2001).

Pregnancy specific protein B (PSPB) is a glycoprotein secreted from the giant binucleate cells of the fetal trophectoderm (Eckblad et al., 1985). PSPB can be detected in jugular blood around day 15 of gestation but does not reach significant amounts until 25 to 30 days (Sasser et al., 1986). Concentrations of PSPB from the periphery have allowed detection of spontaneous embryo mortality between days 24 and 70 (Humblot et al., 1988, 1990) and embryo mortality induced by treatment with Actinomyces pyogenes (Semambo et al., 1992). Animals treated with Actinomyces pyogenes that lost an embryo maintained an elevated concentration of progesterone like that of the pregnant cow until 20 days after embryo death, making progesterone an invalid indicator of pregnancy. While concentrations of progesterone can remain elevated some time after embryonic mortality, concentrations of PSPB, which is no longer being produced by the trophectoderm, fall more quickly to concentrations below that found in pregnant animals, making it a more valid method of pregnancy diagnosis than elevated concentrations of progesterone.

No direct correlation has been reported between concentrations of progesterone and PSPB; however, Weems et al. (1997) proposed that PSPB may have an indirect role in regulating luteal secretion of progesterone through stimulation of prostaglandin $\mathrm{E}$ (PGE). Treatment of the mid-cycle (day 10 to 12) or late (day 17 to 18) bovine CL (Del Vecchio et al., 1995a, b, 1996) or day-16 bovine endometrial tissue (Del Vecchio et al., 1990) with PSPB increased secretion of PGE. Secretion of both $\mathrm{PGE}_{2}$ and $\mathrm{PGF}_{2 \alpha}$ from 
luteal tissue collected late in gestation was stimulated by treatment with PSPB (Weems et al., 1998). Prostaglandin $E_{2}$ stimulated progesterone secretion from luteal tissue collected during this same time, leading to the above conclusion that PSPB has an indirect role in secretion of progesterone. Secretion of both PSPB and progesterone increased earlier in $\mathrm{GnRH}$-treated, repeat-breeding cows than in controls (Mee et al., 1993). It is not known if GnRH directly increased PSPB or if the subsequent rise in progesterone increased PSPB and pregnancy rates in repeat breeding cows after treatment with $\mathrm{GnRH}$ at breeding (Lee et al., 1983; Stevenson et al., 1984, 1988, 1990; Phatak et al., 1986).

As mentioned earlier, IFN- $\tau$ secreted by the bovine conceptus is one of many factors involved in maternal recognition of pregnancy. IFN- $\tau$ induces secretion of an $\alpha$ chemokine, granulocyte chemotactic protein-2 (GCP-2) on days 18 to 26 of gestation (Hansen et al., 1999). The role of this uterine protein is uncertain; however, it may mediate endometrial response to $\mathrm{PGF}_{2 \alpha}$ and also be involved in cell adhesion, inflammation, angiogenic response, or attraction of the conceptus or cells of the immune system to implantation sites (for review see Oppenhein et al., 1991). Austin et al. (1999) reported that treatment of bovine endometrial cells with PSPB-induced secretion of GCP-2. Because PSPB is not secreted in significant amounts until day 25 to 30 of pregnancy, it may control secretion of GCP-2 after maternal recognition of pregnancy and be involved in a later signaling for maintenance of pregnancy.

\section{Genetic Abnormalities}

Embryonic loss may be due to the elimination of chromosomally-abnormal embryos, such as those with genetic deletions or those with permutations for specific 
genes that may be lethal. In humans, approximately half of spontaneously-aborted embryos and fetuses in the first and second trimesters are chromosomally abnormal (Burgoyne et al., 1991). The incidence of genetic abnormalities in beef embryos ranged from $7.2 \%$ to $10.4 \%$ in 9 studies reviewed by Zavy (1994). Many chromosomal abnormalities affect development of the growing embryo, resulting in death; one such gene is the FGF8 gene involved in brain development (Crossley et al., 1996). The most common genetic abnormality in cattle is mixoploidy (King, 1990), which is found more frequently in morphologically-abnormal embryos than in morphologically-normal ones (King et al., 1987).

\section{Influence of the Male}

Some males have lower fertility than their counterparts. Looking at embryonic development to the stage of embryo collection for embryo transfer and then at survival in recipients, differences were noted among bulls (Miller et al., 1992; Coleman et al., 1987). Early cleavage rates of embryos were reduced in bulls with low fertility used in in vitro experiments (Eid et al., 1994). Problems with sperm or semen from bulls of low fertility that indicate incompetence after fertilization can be labeled uncompensable deficiencies and cannot be eliminated by increasing sperm dosage. In a study evaluating pregnancy retention between days 38 and 90 of gestation, Lopez-Gatius et al. (2002) reported that cows bred to one bull of the six used for artificial insemination had a 3.4 times greater risk of pregnancy loss during that time. The nuclear shape within a sperm may be indicative of fertility as it relates to chromosome stability (Ostermeier et al., 2001). Presence of a novel male within the first 48 hours following mating in the mouse induces pregnancy termination by altering the timing of secretion of 
prolactin necessary for pregnancy maintenance (Bruce, 1961).

Embryo quality has been correlated positively with accessory sperm number following fertilization (DeJarnette et al., 1992; Nadir et al., 1993). These authors postulated that larger numbers of accessory sperm per higher quality embryo represent increased competition among potential fertilizing sperm, in agreement with the work of Howard et al. (1993) that the zona pellucida can select against sperm with abnormal head morphology. If the zona pellucida is morphologically selective then the problem with uncompensable deficiencies most likely lies at the DNA level of the sperm. Saacke et al. (2000) reviewed several studies that indicate that this is so.

\section{Infectious Abortion and Embryonic Mortality}

Infectious diseases cause reproductive problems for livestock producers worldwide. The primary indicator of the presence of many of these diseases is the occurrence of abortion. Abortions at any stage of pregnancy increase the days open, usually increase culling rates of otherwise productive animals, and can lead to fewer offspring from which to choose replacement stock. Confounding the problem of occurrence of abortion is the low rate of detection of its causes. Examination of maternal seroconversion (production of antibodies) of antibody titers following abortion, usually taken at abortion and again three weeks later, rarely leads to positive identification for the cause of infectious abortion. Pathological examination of the placenta should be included if possible, as some frequent signs of infectious abortion are the disturbance of fetal and maternal connections of the placenta such as malformations or lesions of the cotyledon.

Bovine Virus Diarrhea Virus (BVD). BVD, sometimes called BVDV, is one of 
the most prevalent causes of abortion in cattle, with an incidence of infection often in excess of $70 \%$ (Paton et al., 1998, Houe, 1999). There are two forms of BVD, cytopathogenic (CP) and noncytopathogenic (NCP). BVD-CP induces apoptotic cell death while NCP replicates in cultured cells without inducing cell death and has the ability to cross the placenta. Because NCP can cross the placenta, any vaccination must be able to protect the fetus. The most frequent carriers of the virus are persistently-infected animals that were infected initially in the uteri of their dams prior to day 125 of gestation (Fray et al., 2000). Infection with BVD-NCP in the first 40 days of gestation causes early embryonic death, infection between 40 and 125 days of gestation results in persistently-infected offspring or later abortion, and infection after 125 days of gestation is nonlethal, as the fetus is now able to mount an immune response (Thur et al., 1997).

Fray (2000) reviewed the effect of BVD on reproductive tissues, primarily the ovary. The virus can be recovered from cells in the oviduct, myometrium, endometrium, and placental membranes. Within the ovary, the virus can be recovered from interstitial, luteal, granulosal and thecal cells, along with follicular fluid. BVD infection in the ovary can cause retarded growth of preovulatory follicles up to two cycles post-challenge (Grooms et al., 1998). In persistently-infected cows, the number and quality of recovered oocytes in response to superovulation was significantly lower than in control cows. Embryos infected with BVD-NCP had a reduced rate of in vitro blastocyst formation when recovered at day-8 post breeding (Bielanski and Dubuc, 1995). Retarded growth may lead to greater mortality rates of early embryos. Utilizing embryo transfer, it is possible to collect BVD-infected embryos and wash them free of the BVD 
virus for transfer into a recipient cow, with no resulting infection of the offspring or recipient. BVD can be transmitted via semen (Meyling and Jensen, 1988), so it is imperative to test new breeding males.

Infectious Bovine Rhinotracheitis (IBR). Sporadic abortions throughout gestation may be caused by IBR. Abortion is most common after the fourth month of gestation, however, Miller et al. (1989) inoculated heifers on day-14 post breeding and within 10 days two heifers showed a decline in progesterone to concentrations similar to those seen at estrus, while an additional two heifers lost embryos on days 40 and 42 after breeding. Inoculation at day-14 postbreeding resulted in early embryonic death, but heifers inoculated on day-21 or -28 postbreeding calved normally (Miller and Van der Maaten, 1986). Histological examination of tissues from infected heifers showed necrosis, hemorrhage, and lymphocyte infiltration of the ovary and $C L$, which may have caused early $C L$ regression, especially in those animals treated prior to maternal recognition of pregnancy (Smith et al., 1990; Miller and Van der Maaten, 1987; Van der Maaten et al., 1985; Van der Maaten and Miller, 1985).

Actinomyces pyogenes. Early embryonic death may be caused by Actinomyces pyogenes. The presence of A. pyogenes in the reproductive tract often is considered to be secondary to other infections, such as endometritis (Anon, 1988). Visual embryonic decomposition and pus were found following abortion from cows infected between days 27 and 41 of pregnancy when compared with cows given prostaglandin to terminate the pregnancy. Cows were, on average, back in heat eight days later with no detrimental effects on subsequent fertility (Semambo et al., 1991).

Other Diseases. The diseases reviewed above are by no means the full extent 
of possibilities for infectious abortions. Many diseases that lead to abortions during late gestation are not relevant to a discussion of causes of embryonic mortality. Other causes of abortion would include Brucellosis and those caused by mycotic factors (for review see McCausland et al., 1987). Campylobacter fetus may cause late term abortion. Studies of cows infected with Campylobacter fetus showed no changes in progesterone, $\mathrm{PGF}_{2 \alpha}$, or PGFM until 24 to 48 hours prior to abortion (Baetz et al., 1980, 1981), similar to the time line for hormonal changes at parturition, once again showing why infectious abortion is difficult to diagnose.

\section{Summary}

The rate of pregnancy retention in cattle can be affected by many factors. Of the many factors involved, no specific ones have yet been identified as primary causes of reduced pregnancy maintenance during the late embryonic and early fetal stages of gestation. The maternal environment is obviously of key importance, however, one cannot discount the role that the external environment may play in pregnancy retention. With average occurrence rates of 7 to $15 \%$ in dairy cattle, late embryonic and early fetal mortality deserve the attention of researchers so that animal management or environment may be altered in an effort to reduce its occurrence. 


\section{STATEMENT OF THE PROBLEM}

Reproductive efficiency in dairy cattle has declined. Butler (1998) reported a decline in first-service conception rates of New York dairy cattle from approximately $65 \%$ in 1951 to $40 \%$ in 1996 . Similar declines have been reported worldwide (Roche et al., 2000; Royal et al., 2000; Macmillan et al., 1996). An increase from 1.62 to 2.91 services per conception between 1972 and 1996 was reported for dairy cattle in Kentucky (Silvia, 1998). Royal et al. (2000) utilized several data banks to make comparisons on measurements of fertility for dairy cattle in the United Kingdom for the years 1975 - 1982 and 1995 - 1998. Pregnancy rate to first service declined from $55.6 \%$ to $39.7 \%$, a decline of almost $1 \%$ each year. The number of cows that had one or more atypical ovulatory hormone patterns increased from $32 \%$ to $44 \%$. The length of the luteal phase increased from 12.9 to 14.8 days while the interovulatory interval increased from 20.2 to 22.3 days. All of these changes appear to have occurred without an increase in days to first service and only a 20-day increase in calving interval, from 370 to 390 days.

Exacerbating the financial problem associated with the decline in fertility is the loss of pregnancy after the cow has been diagnosed pregnant. Although most embryonic losses occur prior to day 16 , recent reports have shown losses between 28 and 42 days to be as high as $45.9 \%$ (El-Zarkouny et al., 2000). Loss rates during this stage of pregnancy averaged approximately 10 to $15 \%$ for dairy cattle, while those in beef cows rarely exceed $4 \%$ without an incidence of infectious abortion.

Little research effort has been devoted to late embryonic and early fetal mortality in cattle since the 1950's and 1960's. The majority of the literature centers on 
embryonic deaths that occur prior to maternal recognition of pregnancy. As emphasis has been placed on selection for milk production, selection for reproductive traits has lost emphasis. However, reproduction is essential to the maintenance of any dairy herd. Modern dairy management plays a large role in reproductive efficiency and may play a role in pregnancy loss in the form of environmental stressors. In this study, the incidence of late embryonic and early fetal mortality was examined on two small dairy operations. Milk production, inseminator, treatment for synchronization of estrus, days postpartum at breeding, body condition score and any incidence of illness were recorded. Serum was collected and examined to investigate the hormonal factors in the maternal environment in which these embryos were developing. 


\section{MATERIALS AND METHODS}

\section{Animals and Synchronization of Estrus}

Lactating dairy cows and heifers (193 Holstein, 17 Ayrshire and 1 Guernsey) on two West Virginia farms were used. After palpation of the reproductive tract and ovaries, some cows received either a single injection of $\mathrm{PGF}_{2 \alpha}(25 \mathrm{mg}$, i.m., $\mathrm{n}=6)$ or $\mathrm{PGF}_{2 \alpha}$ followed 48 hours later by estradiol benzoate $(400 \mu \mathrm{g}$, i.m., $\mathrm{n}=46)$ for synchronization of estrus. Cows displaying spontaneous or synchronized estrus were inseminated either artificially, 12 hours after the onset of standing estrus, or by natural service. The day of insemination was designated as day 0 of gestation.

Age of animals ranged from 1.5 to 8 years (average $3.4 \pm 1.8$ years), and cows were in their first to sixth lactation. Cows ranged from 23 to 388 days postpartum (average $137 \pm 75$ days) at insemination and were between 2.25 to 4.5 ( 5 point scale, Wildman et al., 1982; average $3.1 \pm 0.4$ ) in body condition score at first pregnancy examination. Information was collected from farm records on age, parity, service number, cow's sire, current service sire, inseminator, days postpartum at breeding and milk production from days 28 to 60 of gestation (Farm 2 only).

Animals on both farms had been vaccinated against IBR, BVD (types I and II), $\mathrm{PI}_{3}$, and the five most common strains of leptospirosis. Test results for leucosis and Johne's Disease were negative for Farm 1 animals. Farm 2 animals were negative for Johne's Disease and brucellosis. Because there was no reported incidence of disease for the duration of the study, it was believed that disease played little or no role in pregnancy loss. 


\section{Determination of Pregnancy Loss}

At Farm 1, cows $(n=141)$ were examined for pregnancy once between days 30 and 36 after insemination. Followed by an examination of pregnant animals between 58 and 67 days after insemination. Most pregnant animals were re-examined between days 45 and 51 to time early losses of pregnancy more precisely. At Farm 2, cows ( $n=$ 70) were examined for pregnancy at 28 to 30 days after insemination and were reexamined daily or three times per week until 45 days, then every 5 days until day 60 during the early part of the study. Pregnancy was confirmed by visualization of an embryonic heartbeat by transrectal ultrasonography (Aloka 500 [Corometrics Medical Systems, Wallingford, CT] fitted with a $7.5 \mathrm{MHz}$ rectal probe). Records were taken at each examination on the sizes and locations of follicles $\geq 5 \mathrm{~mm}$ and corpora lutea. Cows with a detected pregnancy at 28 to 37 days (211 of 384 examined; $55 \%$ ) were used in the study.

\section{Blood Collection and Radioimmunoassays}

A blood sample $(8 \mathrm{ml})$ was collected by coccygeal or jugular venipuncture at each examination. Following collection, samples were placed on ice immediately and later were transported to the laboratory. Samples were refrigerated at $4^{\circ} \mathrm{C}$ for 12 to 24 hours before centrifugation for 30 minutes at $3000 \mathrm{~g}$. Serum was harvested and frozen at $-20^{\circ} \mathrm{C}$, until concentrations of progesterone were determined by radioimmunoassay (Sheffel et al., 1982).

\section{Analyses of Data}

On both farms, data for concentrations of progesterone were examined for a single serum sample from each cow that corresponded to each of three stages of 
gestation ( 28 to 37,45 to 51 and 58 to 67 days). For each of the first two stages, concentrations of progesterone were ranked from least to greatest and then divided into three classifications (low quarter, middle half and high quarter) and the effect of progesterone on pregnancy retention beyond that stage was evaluated using chi square analysis.

The frequent examinations on Farm 2 allowed for a closer examination of progesterone patterns, in addition to the single sample evaluated from each time period. Complete serum samples from a subset of six animals were chosen at random to represent each of the following groups: Holstein cows, Ayrshire cows, Holstein heifers and Ayrshire heifers. Complete serum samples from the five animals at this farm that did not maintain pregnancy also were analyzed. Comparisons of patterns of progesterone over time were made using linear regression to evaluate effect of breed, age and breed by age interaction. Comparisons within patterns of progesterone over time in Holstein cows that maintained pregnancy and those that did not were examined using linear regression. Student's t-test was used to determine differences between mean concentrations of progesterone.

Effect of size of the largest follicle $(\geq 5 \mathrm{~mm})$ and size of the two largest follicles on either ovary on pregnancy retention was tested by chi square analysis. Analyses were done for 28 to 36 days and 45 to 51 days of gestation. A total of 55 different sires were used as service sires during the study. Only the four sires most frequently used ( $n=10$ to $31 \mathrm{cows} / \mathrm{sire}$ ) were evaluated for effects on percent pregnancies maintained, as determined by chi square analysis, with no corrections made for age or body condition of cows. 
Using chi square analysis, classifications were used to examine for effects of age, service number, body condition score, milk production, total luteal area $(1 / 2$ width $x$ $1 / 2$ height $x \pi$ ), parity, days postpartum and synchronization treatment on pregnancy retention. Using the information collected for each cow, three groups were established for each variable usually by dividing the cows into approximately the low quarter, middle half, and high quarter for each variable. To determine if there was an effect on pregnancy retention from the interaction of body condition score and age, data were examined using ANOVA followed by Tukey's test (SAS, 1985). 


\section{RESULTS}

\section{Timing of Embryonic/Fetal Mortality}

Of the original 384 cows bred, $55 \%$ were pregnant at 28 to 37 days and $49 \%$ were pregnant at 58 to 67 days of gestation. On Farm 1, 19 of 141 and on Farm 2, 5 of 70 pregnancies were lost, which did not differ so data were pooled. Of the 211 cows pregnant at 28 to 37 days, $24(11.4 \%)$ did not maintain pregnancy to 58 to 67 days of gestation. Losses between days 28 to 37,45 to 51 , and 58 to 67 were determined by ultrasonography. To determine losses that occurred between the three examinations, visual signs, such as standing estrus and discharge of blood or off-color mucus, were used to indicate losses and were confirmed by later ultrasonography or rectal palpation. Losses were distributed as follows: 28 to 37 days $=5,38$ to 44 days $=5,45$ to 51 days $=7,52$ to 56 days $=2$, and 57 to 67 days $=5$. Late embryonic $(\leq 45$ days $)$ mortality accounted for $41.7 \%$ (10 of 24 ) of losses, fetal mortality (>45 days) accounted for $29.2 \%$ (7 of 24) of losses. Seven losses could not be determined with certainty as they were detected during the days of 45 to 51 , but could have occurred before day 45 .

\section{Number of Corpora Lutea}

Two corpora lutea were detected in $10.4 \%$ of the animals, indicating that these animals had potentially ovulated more than one oocyte. Embryos were not counted at the initial diagnosis of pregnancy, so the actual number of embryos is not known. In 14 of 22 cases, each corpus luteum was located on a separate ovary. The number of corpora lutea had no effect on concentrations of progesterone at any of the three periods (Table 1$)$. Pregnancy retention was reduced $(P<0.01$, Figure 1$)$ in animals with two corpora lutea compared to those with a single corpus luteum $(72.7 \%$ vs. 


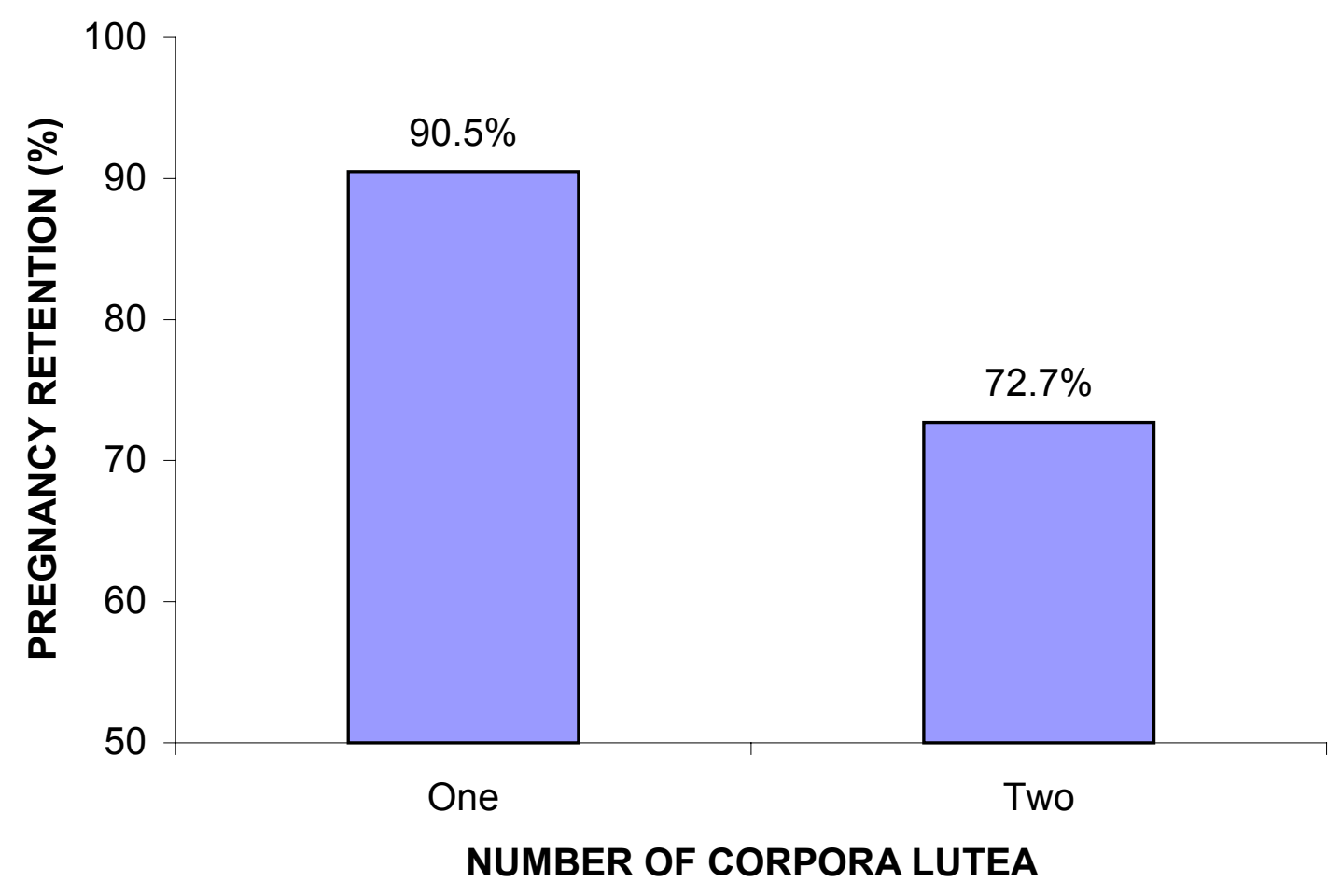

Figure 1. Effect of number of corpora lutea on pregnancy retention to 58 to 67 days ( $P$ $<0.01 ; \mathrm{n}=189$ and 22 , respectively). 
Table 1. Concentrations of progesterone in cows with one or two corpora lutea

\begin{tabular}{|c|c|c|c|}
\hline \multirow{3}{*}{$\frac{\text { Stage of Pregnancy }}{28 \text { to } 37 \text { days }}$} & No. of Corpora Lutea & $\mathrm{n}$ & Progesterone $(\mathrm{ng} / \mathrm{mL})$ \\
\hline & One & 174 & $5.1 \pm 2.1$ \\
\hline & Two & 22 & $5.3 \pm 3.0$ \\
\hline \multirow{2}{*}{45 to 51 days } & One & 157 & $5.2+1.8$ \\
\hline & Two & 17 & $5.7 \pm 1.6$ \\
\hline \multirow[t]{2}{*}{58 to 67 days } & One & 164 & $5.1 \pm 1.7$ \\
\hline & Two & 18 & $6.1+2.8$ \\
\hline
\end{tabular}

90.5\%). Distribution of loss in double ovulators was equal between the embryonic and fetal periods (13.6\% of animals pregnant at 28 to 37 days in each period). However, cows with a single corpus luteum that lost pregnancy did so more often prior to day 45 ( $6.4 \%$ vs. $3.2 \%$ of those pregnant at 28 to 37 days).

\section{Concentrations of Progesterone}

Pregnancy retention to 58 to 67 days was associated $(P<0.05)$ with concentrations of progesterone in serum at days 28 to 37 of gestation, but unrelated to concentrations of progesterone at 45 to 51 days of gestation $(\mathrm{P}>0.05$; Table 2$)$. Cows with low progesterone at 28 to 37 days of gestation were more likely to experience embryonic mortality by 58 to 67 days, especially loss that occurred before 45 to 51 days $(P<0.01)$. Pregnancy maintenance in the groups with medium and high progesterone did not differ (91\% and 92\%), however, cows with low progesterone maintained only $77 \%$ of pregnancies to 58 to 67 days. Closer examination of the data for the group of cows with low concentrations of progesterone at days 28 to 37 (mean $3.0 \pm 0.8 \mathrm{ng} / \mathrm{mL}$ ) seemed warranted. For cows below the mean, $63 \%$ maintained pregnancy to 45 to 51 days and $56 \%$ maintained pregnancy to 58 to 67 days. The value at or below which only $50 \%$ of the pregnancies were retained was $2.8 \mathrm{ng} / \mathrm{mL}$. Despite having a viable pregnancy, concentrations of progesterone were below $1 \mathrm{ng} / \mathrm{mL}$ in two animals between 
Table 2. Effect of concentrations of progesterone at two stages of gestation on retention of pregnancy

\begin{tabular}{|c|c|c|c|c|c|}
\hline \multirow{2}{*}{\multicolumn{2}{|c|}{ Days of Gestation }} & \multicolumn{4}{|c|}{ Classification of Concentration of Progesterone $(\mathrm{ng} / \mathrm{ml})$} \\
\hline & & Low & Medium & High & Total \\
\hline \multirow[t]{5}{*}{28 to 37} & $\mathrm{n}$ & 49 & 98 & 49 & 196 \\
\hline & Range & $0.4-3.76$ & $3.78-5.98$ & $5.99-16.99$ & $0.42-16.99$ \\
\hline & Mean & $3.0 \pm 0.8$ & $4.7 \pm 0.6$ & $8.0+2.3$ & $5.1+2.2$ \\
\hline & $\%$ Retention to 45 to $51 \mathrm{~d}$ & $80^{a}$ & $9 \overline{6}^{\mathrm{b}}$ & $96^{\mathrm{b}}$ & 92 \\
\hline & $\%$ Retention to 58 to $67 \mathrm{~d}$ & $77^{\mathrm{a}}$ & $91^{\mathrm{b}}$ & $92^{b}$ & 88 \\
\hline \multirow[t]{4}{*}{45 to 51} & $\mathrm{n}$ & 44 & 86 & 44 & 174 \\
\hline & Range & $1.6-3.99$ & $4.00-6.16$ & $6.22-12.6$ & $1.63-12.6$ \\
\hline & Mean & $3.3+1.0$ & $5.0+1.2$ & $7.5+2.0$ & $5.2+1.7$ \\
\hline & $\%$ Retention to 58 to $67 \mathrm{~d}$ & $9 \overline{8}^{\mathrm{b}}$ & $9 \overline{4}^{\mathrm{b}}$ & $96^{\mathrm{b}}$ & 95 \\
\hline
\end{tabular}

* Data shown are only for animals from which a blood sample was available. Classification was based on the lower $25 \%$, middle $50 \%$, and upper $25 \%$ of ranked values for concentrations of progesterone. $a, b$ Values in the same row with different letters differ $(P<0.05)$.

days 28 to 37 of gestation. A corpus luteum was visible and appeared to be of normal size in both of the animals. Concentrations of progesterone had recovered in one animal by the next examination, before the pregnancy was lost between 45 and 52 days of gestation.

Using the data collected more frequently from Farm 2, patterns of progesterone over time were compared among groups of animals based on age and breed. Only an effect of time was found, with no differences among groups. No differences were found when comparing concentrations of progesterone over time in Holstein cows that did or did not maintain pregnancy. The individual animals that did not maintain pregnancy are compared to the average for Holstein cows in Figure 2, because all Ayrshires and all Holstein heifers maintained pregnancy. The final day that the embryo from each animal was viable is denoted with a circle. A major decrease in progesterone below the breed mean for random cows was observed before that date in only one cow (\#987). The concentration of progesterone in that cow was $2 \mathrm{ng} / \mathrm{mL}$ when the embryo was no longer viable, thus embryonic death always preceded luteal regression. Cow \# 938 was 


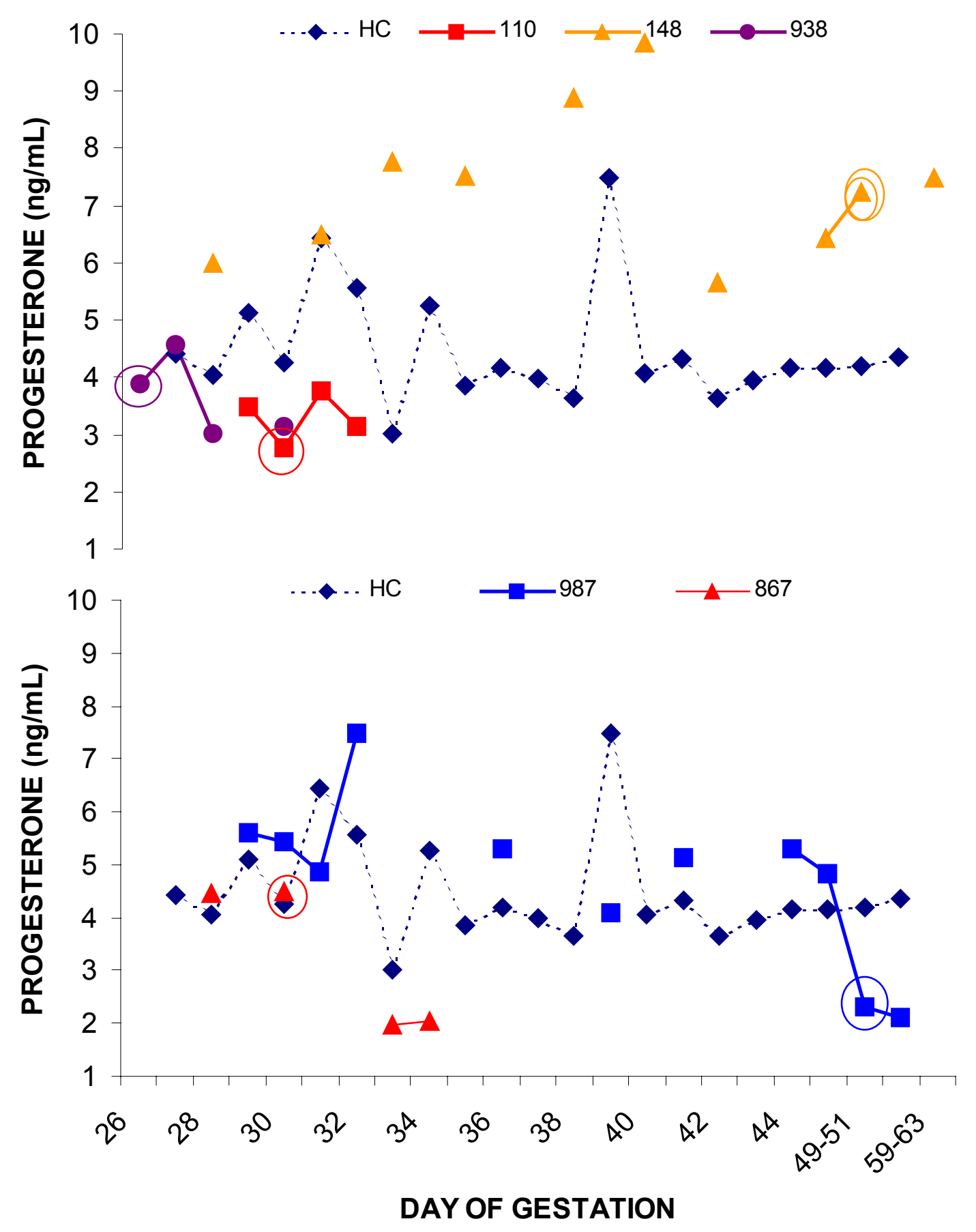

Figure 2. Patterns of concentrations of progesterone for 5 animals from Farm 2 that did not maintain pregnancy. The dashed line represents the average progesterone for 6 randomly selected Holstein cows that maintained pregnancy. Circles denote the last day the embryo was viable. Cow \#148, pregnant with twins, lost both embryos. 
examined for two days prior to day 28 , unlike the remainder of animals on the study.

\section{Cow Characteristics and Other Factors}

Cows were divided into three groups for primary analysis of effects of body condition: scores of 2.25 to $2.50,2.75$ to 3.25 and 3.5 and over. Body condition score of cows at first examination affected rate of pregnancy retention $(P<0.05)$. Those cows in greater body condition maintained significantly fewer pregnancies than those of average or low condition (Figure 3). Animals were divided into three age categories: heifers, cows 2 to 4 years old and cows 5 years old or greater. Age of the cow affected pregnancy retention $(P<0.05$; Figure 4$)$. All $(n=22)$ of the heifers on the study maintained pregnancy beyond 67 days, which was a significantly higher percentage than that for older cows ( $81 \%$ ). Younger cows ( 2 to 4 years) tended to maintain more pregnancies than older cows $(P=0.09)$. There was no interaction between age and body condition as determined by ANOVA followed by Tukey's Test.

Of the four sires used most frequently, one had a significantly lower pregnancy retention rate (Figure 5a). Of those same four sires, two had lower pregnancy rates at the conclusion of the study compared to the natural service sire (Sire \#4) when all cows bred to those bulls that did or did not become pregnant were included (Figure 5b). There were no effects of number of services, days postpartum at breeding, inseminator, parity, or milk production between days 28 and 60 of gestation. The two largest follicles $\geq 5 \mathrm{~mm}$ on each ovary were recorded at examination. Neither diameter of the largest follicle, nor diameter of the two largest follicles on either ovary affected pregnancy retention at any period. Size of the corpus luteum, as determined by total luteal area $(1 / 2$ width $\times 1 / 2$ height $x \pi$ ), had no effect on pregnancy retention and was not correlated with 


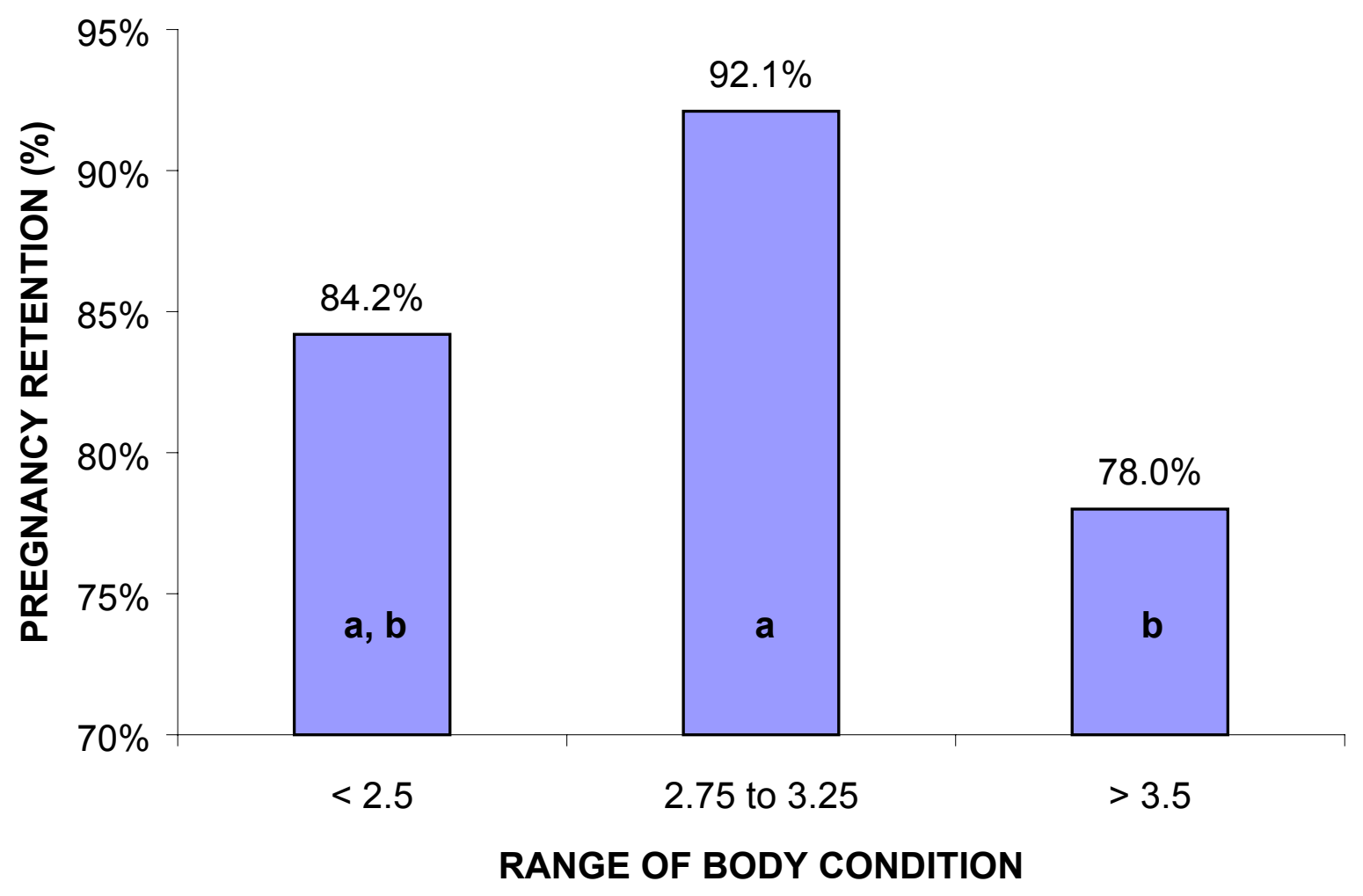

Figure 3. Effect of body condition score on pregnancy retention. Bars with different letters differ $(P<0.05 ; n=19,151$ and 41, respectively). 


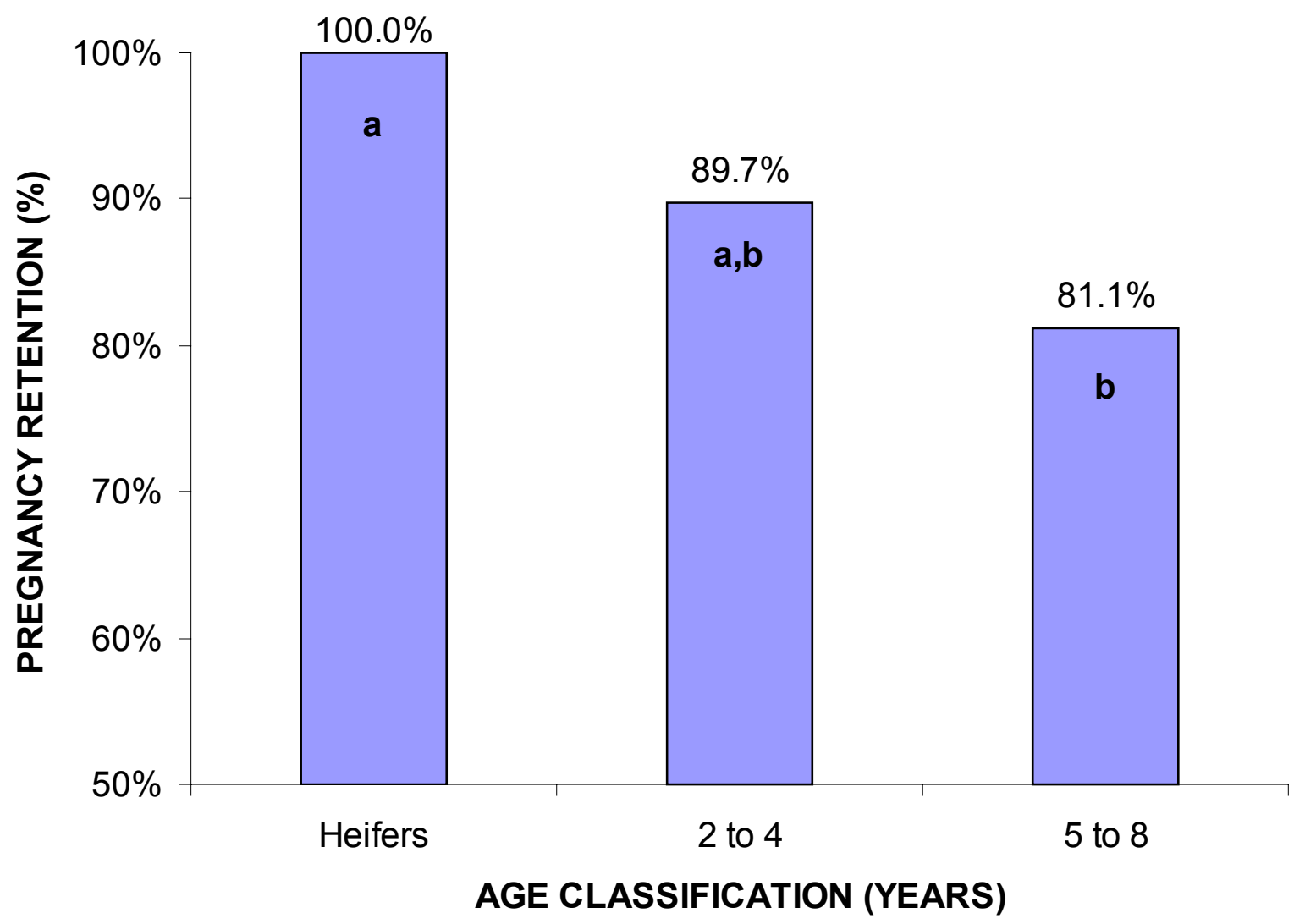

Figure 4. Effect of age on pregnancy retention. Bars with different letters differ $(P<$ $0.05 ; n=22,136$ and 53, respectively). 
A.

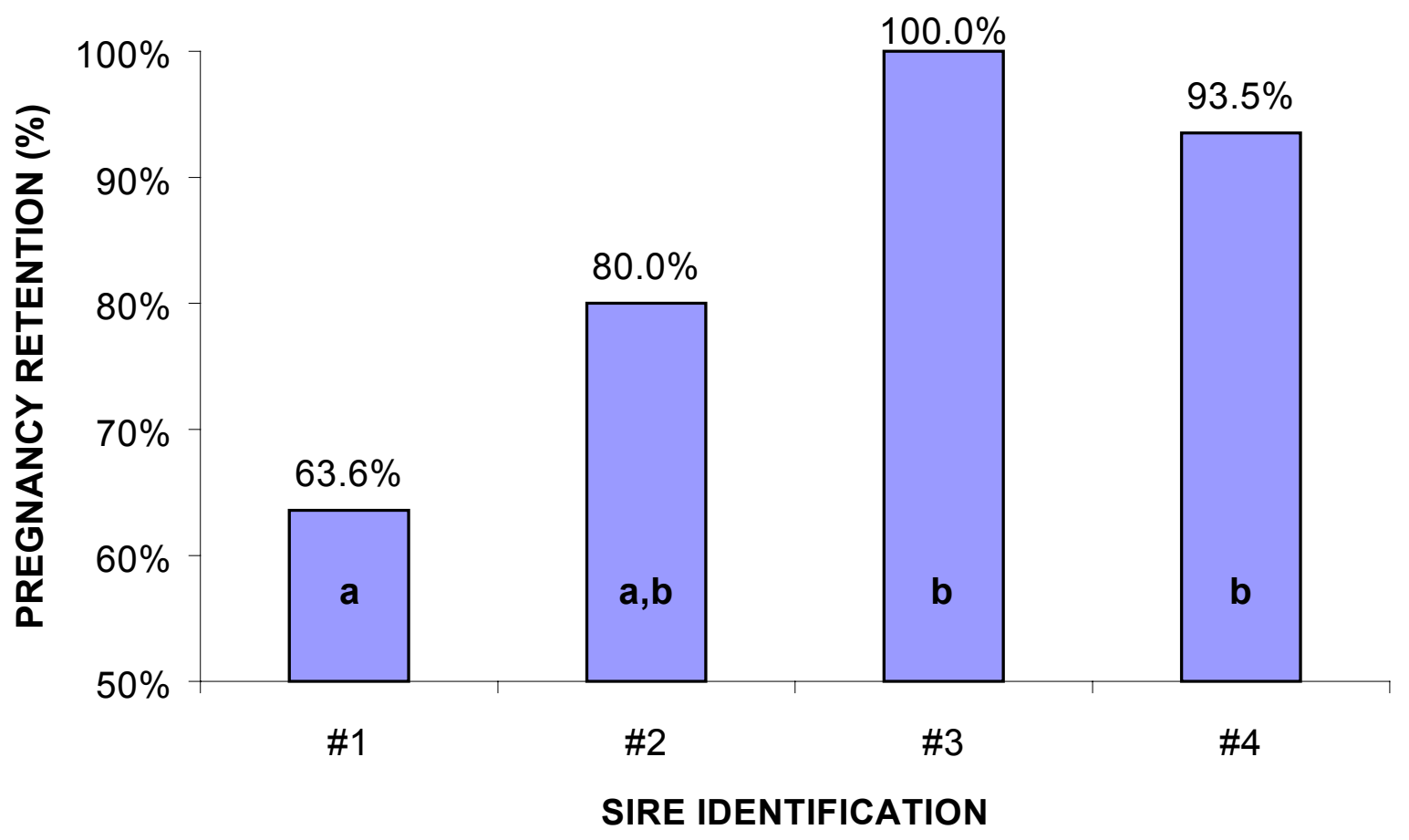

B.

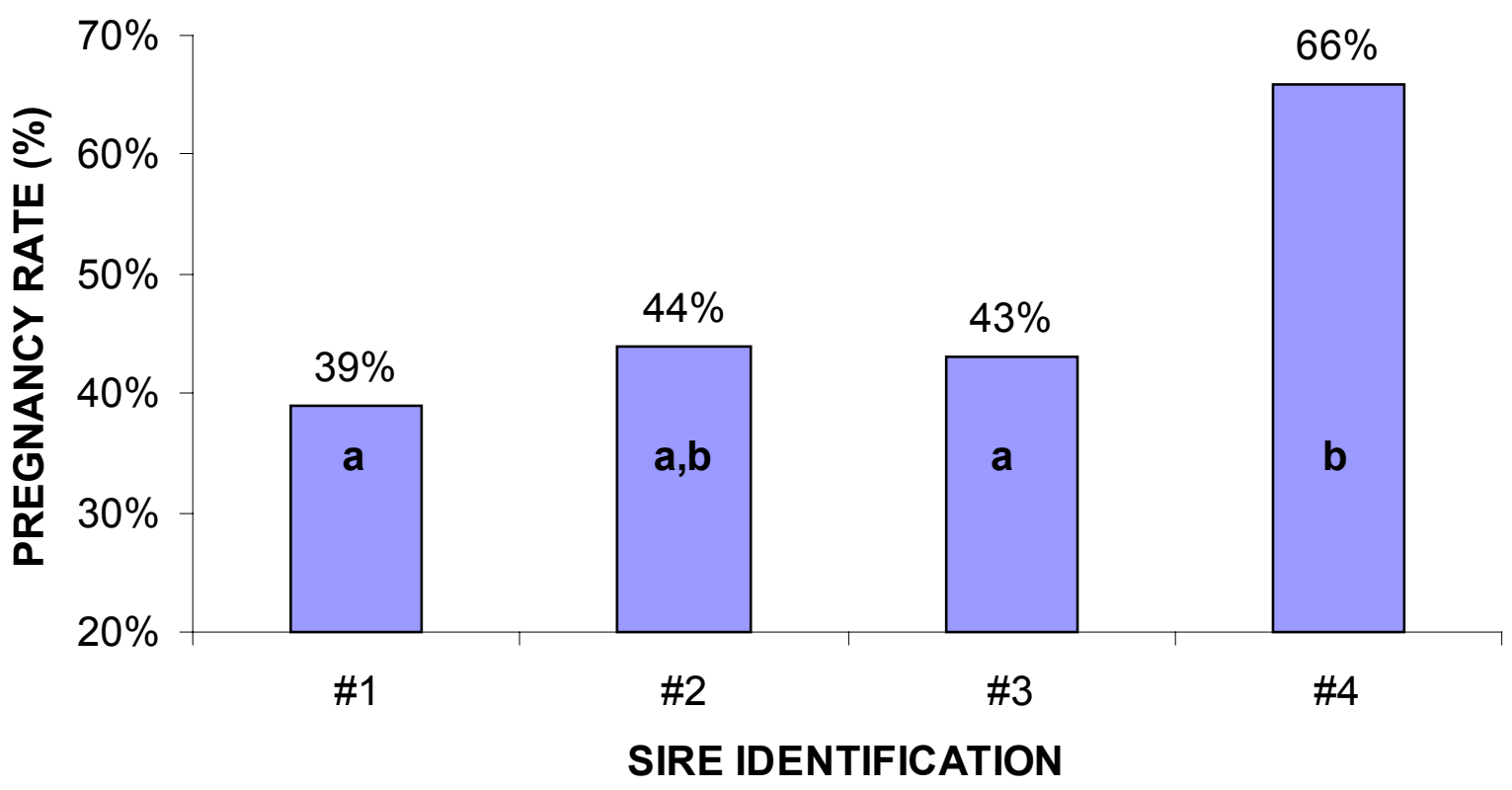

Figure 5. A) Variation among the four most frequently used sires in pregnancy retention. Bars with different letters differ $(P<0.05 ; n=11,10,12$ and 31, respectively). B) Variation among the four most frequently used sires in pregnancy rate at conclusion of the study. Bars with different letters differ $(P<0.05 ; n=18,18,28$ and 44 respectively). 
concentrations of progesterone at either time period.

\section{Embryonic Growth}

Using the data collected frequently on the 70 animals from Farm 2, averages for estimated embryonic size between days 28 and 61 of gestation are shown in Figure 6 . Measurements were available for only 10 of the 24 embryos lost. None of the embryos $17 \mathrm{~mm}$ and over from crown to rump at 28 to 37 days were lost. Those embryos lost were between 9 and $16 \mathrm{~mm}$, however pregnancy retention was not related to the estimated sizes of the embryos at either days 28 to 37 or 45 to $51(P>0.05)$. 


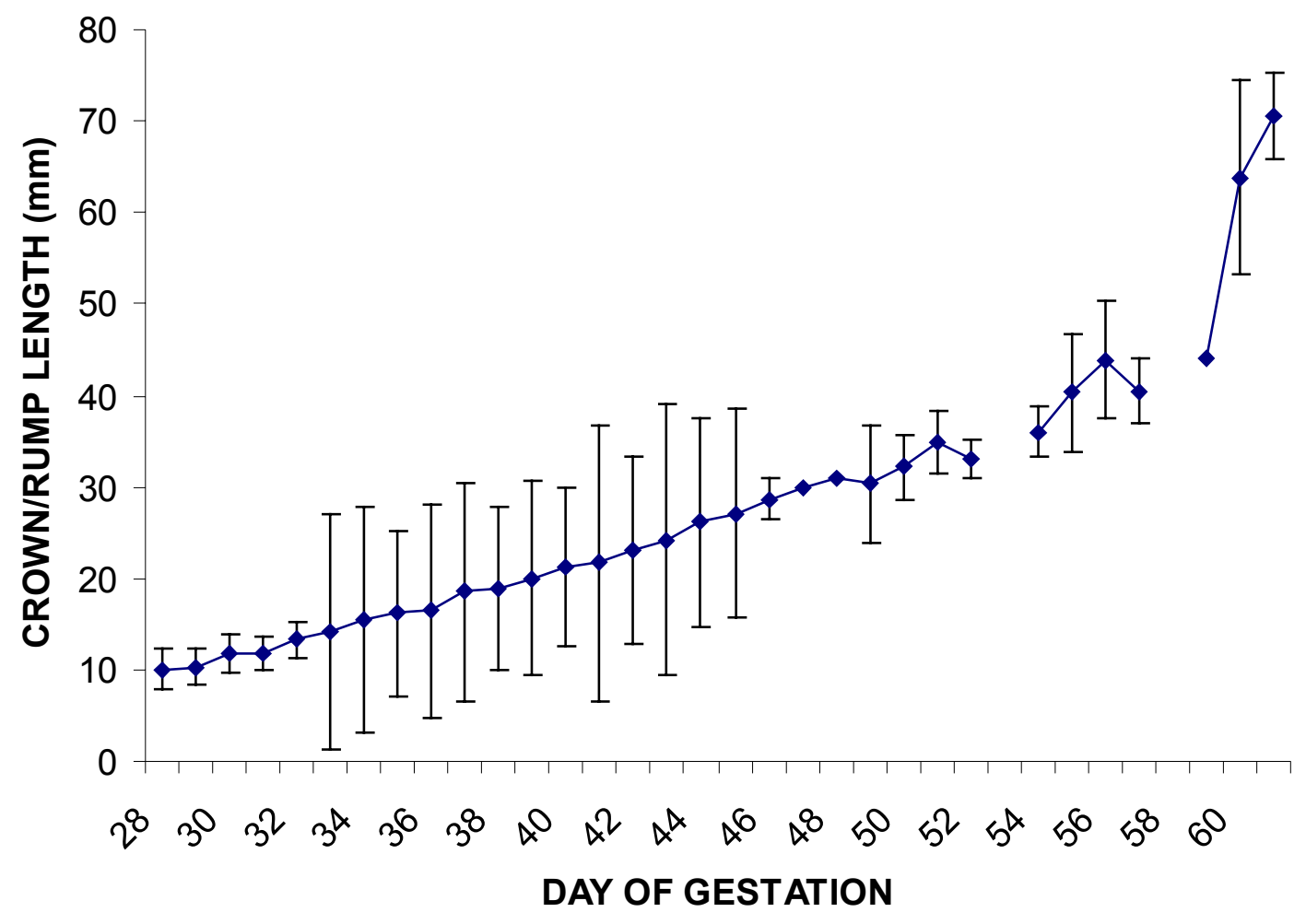

Figure 6. Average sizes of embryos between days 28 and 61 of gestation as determined from ultrasonography of 70 animals. 


\section{DISCUSSION}

Pregnancy was not maintained in 24 of 211 cows $(11.4 \%)$. This falls within the range of estimated losses of 7 to $12 \%$ between days 24 to 75 , as determined by concentrations of milk progesterone (Kummerfield et al., 1978; Bulman and Lamming, 1979) and just below the estimated loss rates for lactating dairy cows synchronized with the Ovsynch protocol (reviewed by Inskeep, 2002). The percentage of estimated embryonic loss, $7.1 \%$, and that of fetal loss, $4.3 \%$, falls within the ranges present in the literature.

When the cows pregnant with twins are excluded, only $2.6 \%$ of the cows pregnant at 45 days failed to maintain pregnancy. Attachment of the embryonic placenta and maternal tissue begins by day 30 of gestation and has spread to the body of the gravid horn by day 35 and to the contralateral horn by day 38 (Melton et al., 1951). Villi and crypts form in the placentome where caruncular (maternal) and cotyledonary (embryonic) tissue meet. Between days 33 and 36 of gestation, the villi rapidly increase in length and branching, with little change after 42 days of gestation (King et al, 1979). Failure of the placenta to join with the maternal tissue or failure of the villi to branch sufficiently may result in pregnancy loss from inadequate nutrient transfer to the developing embryo.

Two corpora lutea were detected in $10.4 \%$ of the cows. These animals potentially had ovulated more than one oocyte, which may have resulted in multiple pregnancies. Unfortunately, data were not recorded on how many of these animals had multiple viable embryos at initial pregnancy detection, so conclusions cannot be drawn regarding whether the loss was of one or two embryos. In data from commercial 
slaughter plants (Hanrahan, 1983) and from a population of beef cattle selected for twinning (Echternkamp et al., 1990), approximately $50 \%$ of twin ovulations resulted in twin pregnancies or births. Once multiple embryos were diagnosed, no single losses (one of two embryos) were recorded up to days 58 to 67 of gestation; any losses were of both embryos. Echternkamp (1987) reported that the death of a single fetus within an anastomosed placental unit resulted in the death of all remaining fetuses in that unit. Anastomosis of the placenta occurs in about $90 \%$ of twin pregnancies in cattle, but in only $10 \%$ of pregnancies from the litter bearing pig (Vogt, 1968).

Those animals with two corpora lutea maintained fewer pregnancies to 67 days than cows with a single corpus luteum $(72.7 \%$ vs. $91.0 \%)$. Numerically, distribution of loss in cows with two corpora lutea was equal between the embryonic and fetal periods while cows with a single corpus luteum lost a greater percentage prior to day 45 . Similar results were reported by Echternkamp and Gregory (1999) looking at pregnancy losses in beef cattle; $12.4 \%$ of cows carrying twins failed to maintain pregnancy to term and only $3.5 \%$ of cows carrying a single offspring failed to do so. Distribution of loss was equal before and after 100 days of gestation in cows carrying twins, whereas most loss occurred prior to 100 days in those with a single embryo or fetus.

Mean concentration of progesterone did not differ significantly between animals with one or two corpora lutea. Pope et al. (1969) reported that peak peripheral concentrations of progesterone from cows with two corpora lutea did not differ from those of cows with one corpus luteum during the estrous cycle. Weight of corpora lutea in cows with FSH-induced multiple ovulations was related inversely to the number of corpora lutea (Echternkamp, 1992). The decrease in corpus luteum weight may imply 
decreased output of progesterone in cows with multiple corpora lutea that would lead to no difference in peripheral concentrations of progesterone. Interestingly, the minimal amount of progesterone needed to maintain a bilateral pregnancy following bilateral ovariectomy was greater than that needed to maintain a single pregnancy (Tanabe, 1966). In the ewe, concentrations of progesterone were greater in the uterine horn and uterine artery adjacent to the corpus luteum-bearing ovary than in the contralateral horn (Weems et al., 1989). Pope et al. (1982) also reported increased concentrations of progesterone in uterine tissue nearest the corpus luteum in the cow.

Pregnancy maintenance to 67 days was related to concentrations of progesterone at 28 to 37 days of gestation, but unrelated to concentrations at 45 to 51 or 58 to 67 days. Those cows with low concentrations of progesterone at day 28 to 37 were more likely to experience late embryonic mortality. Except for four animals with concentrations of progesterone below $1 \mathrm{ng} / \mathrm{mL}$, the concentrations of progesterone found in this study were similar to reported values for pregnant females (Erb et al., 1968; Donaldson et al., 1970). Three of the four animals had concentrations of progesterone below $1 \mathrm{ng} / \mathrm{mL}$ between days 28 and 37 . In two of these cows, the embryo was viable at examination and blood sampling and a normal sized corpus luteum was visible in all three animals. None of the four animals with concentrations of progesterone below $1 \mathrm{ng} / \mathrm{mL}$ maintained pregnancy to the end of the study. The concentration of progesterone in serum is related to both its production and clearance rates. Further studies are needed to examine the concentrations of progesterone and the amounts of enzymes for production of progesterone in corpora lutea collected from cows at the same stage of gestation that have either low or high serum concentrations 
of progesterone.

Embryonic death preceded luteal regression in animals in which peripheral concentrations of progesterone appeared adequate to maintain pregnancy and were similar to those for the average Holstein cow. During early placentation, peripheral concentrations of progesterone that are slightly lower than the average may be insufficient to maintain pregnancy (as shown by cow \#110 in Figure 2). This may be the result of reduced luteal output or increased metabolism of progesterone. In some cases unexplained decreases in peripheral concentrations of progesterone may be the result of late embryonic or early fetal mortality. Alternatively, an insult to the corpus luteum, such as an extremely high concentration of $\mathrm{PGF}_{2 \alpha}$ (Schallenberger et al., 1989), reducing output of progesterone, may have occurred and resulted in late embryonic or early fetal mortality in other animals. As evidenced by the variability of peripheral concentrations of progesterone in these five animals alone, there is no clearly defined time-point or defined cause of late embryonic or early fetal mortality when evaluating peripheral concentrations of progesterone.

Increased metabolism of progesterone may be responsible for lower serum concentrations of progesterone. High producing cows in early lactation have a higher rate of metabolism than low producing cows (Huntington, 1990; Butler, 2000). The level of nutrition did not alter the concentration of progesterone in either luteal tissue or ovarian venous blood of ewes (Abecia et al., 1995, 1997) and cows (Apgar et al., 1975). Those data indicate that variation in peripheral blood progesterone is most likely caused by differences in metabolism of progesterone. In ovariectomized cows receiving exogenous progesterone from an intravaginal device, Ahmad Rabiee, from the 
University of Melbourne in Australia (personal communication), reported a negative relationship between the level of feeding and plasma concentrations of progesterone. However, smaller corpora lutea have been reported in undernourished cows (Bossis et al., 1999; Apgar et al., 1975; Gombe and Hansel, 1973). Apgar and co-workers (1975) measured in vitro output of progesterone following LH stimulation and found that output by corpora lutea from nutritionally-restricted animals did not increase to concentrations as great as control animals.

Age was a significant factor in pregnancy retention. All 22 of the heifers maintained pregnancy through 58 to 67 days, while losses in lactating cows increased with age. In an additional study on three farms, pregnancy retention was examined in dairy heifers from 30 to 66 days (unpublished data); $97.3 \%$ (72/74) heifers maintained pregnancy. Aged dairy cows are uncommon in the modern dairy industry as they are often culled before six years of age.

Cows in greater body condition (3.50 and greater) maintained fewer pregnancies than those in median condition. Progesterone metabolism could reduce pregnancy retention by cows in better condition as those cows would be expected to eat more to maintain condition. However, body condition and peripheral concentrations of progesterone were not correlated. Maintenance of a desirable body condition can be difficult in dairy animals. Lactation places great demand on the cow and those early in lactation are commonly in a negative energy balance. Later in lactation, cows are able to reestablish some condition as milk production begins to decline. Older cows that are not growing and lactating would be expected to maintain condition more easily, however, there was no correlation between age and body condition in the cows in this 
study.

One of the four most-frequently-used sires had a significantly lower pregnancy retention rate. Lopez-Gatius et al. (2002) reported that cows bred to one of the six sires used resulted in a 3.4 times higher risk of pregnancy loss between 38 and 90 days of gestation. Such sires may carry a genetic abnormality that is lethal between the developmental stages of 28 to 67 days of gestation, although the likelihood of such an abnormality would be low. All of the sires except for the single bull used for natural service on Farm 1 were available from large, reputable semen suppliers and it is unlikely that any would have been known to exhibit poor fertility. When evaluating the number of cows pregnant at the end of the study compared with the number of cows serviced per sire, the cows bred to two sires had lower pregnancy rates than the one natural-service sire.

No effects of number of services, days postpartum at breeding, parity, or milk production between days 28 to 60 days of gestation were seen. High producing cows have decreased conception rates (Stevenson et al., 1983). In the current study, high producing cows on Farm 2 were just as likely to maintain a pregnancy as lower yielding cows following a successful conception. Adequate heat detection is a problem that limits fertility among dairy cows, especially on those farms that rely solely on artificial insemination. Standing estrus may go unobserved, resulting in cows being bred later in lactation or inseminated at the improper time, which lowers pregnancy rates due to compromised oocyte quality or sperm viability (Saacke et al., 2000). Delaying breeding beyond 60 to 90 days postpartum did not appear to increase chances of pregnancy retention from 28 to 67 days following a successful service. 
Neither size of the largest follicle on either ovary, nor the size of the two largest follicles on either ovary affected pregnancy maintenance at any time period. The ovary is the predominant source of estradiol and changes in the growth patterns of follicles may be important during pregnancy. The dosage of melengestrol acetate that maintained pregnancy in beef heifers bilaterally ovariectomized at 56 days of gestation was not adequate to maintain pregnancy in unilaterally-ovariectomized heifers when the remaining ovary did not have a CL (Zimbelman and Smith, 1966). McDonald (1952) reported that it took more progesterone to maintain a pregnancy in a cow in which only the corpus luteum had been removed and the ovary remained compared to an ovariectomized cow, however this was based on the observation of a single ovariectomized cow.

Estimated embryo size at 28 to 37 days did not affect pregnancy retention. Small embryos were just as likely to survive as larger embryos. Embryonic growth appeared to follow a quadratic growth pattern, as reported by Curran (1986). Larger embryos have the capacity to produce more IFN- $\tau$ during maternal recognition of pregnancy (Farin et al., 1990), which may result in increased pregnancy rates from more developmentally-advanced embryos.

In summary, late embryonic and early fetal mortality in dairy cattle can be affected by many factors. Some primary factors appear to be concentrations of progesterone at 28 to 37 days of gestation, body condition and age of the cow. Placental attachment is occurring between 28 to 37 days of gestation and progesterone may play an important role in either the implantation process or maintenance of the embryo through this phase. Further study is needed to determine if either reduced 
luteal function from decreased amounts of enzymes necessary for production of progesterone or metabolism of progesterone are primary reasons for lower peripheral concentrations of progesterone during this time. 


\section{LITERATURE CITED}

Abecia, J. A., Lozano, J. M., Forcada, F., and Zarazaga, L. 1997. Effect of level of dietary energy and protein on embryo survival and progesterone production on day eight of pregnancy in Rasa Aragonesa ewes. Anim. Reprod. Sci. 48:209-218.

Abecia, J. A., Rhind, S. M., Bramley, T. A., and McMillen, S. R. 1995. Steroid production and $\mathrm{LH}$ receptor concentrations of ovarian follicles and corpora lutea and associated rates of ova wastage in ewes given high and low levels of food intake before and after mating. Anim. Prod. 61:57-62.

Albihn, A., Gustafsson, H., Hurst, M., and Rodriguez-Martinez, H. 1991. Embryonic ability to prolong the interoestrous interval in virgin and repeat breeder heifers. Anim. Reprod. Sci. 26:193-210.

Alliston, C. W. and Ulberg, L. C. 1961. Early pregnancy loss in sheep at ambient temperature of $70^{\circ}$ and $90^{\circ} \mathrm{F}$ as determined by embryo transfer. J. Anim. Sci. 24:912. (Abst.).

Anon. 1988. VIDA report ADAS. In: Ministry of Agriculture Fisheries and Food Central Veterinary Laboratory. Weybridge.

Anderson, G. B., BonDurant, R. H., and Cupps, P. T. 1982. Induction of twins in different breeds of cattle. J. Anim. Sci. 54:485-590.

Anderson, G. B., Cupps, P. T., Drost, M., Horton, M. B., and Wright, R. W. 1978. Induction of twinning in beef heifers by bilateral embryo transfer. J. Anim. Sci. 46:449452.

Apgar, J., Aspros, D., Hixon, J. E., Saatman, R. R., and Hansel, W. 1975. Effect of restricted feed intake on the sensitivity of the bovine corpus luteum to LH in vitro. J. Anim. Sci. 41:1120-1123.

Austin, K, J., King, C. P., Vierk, J. E., Sasser, R. G., and Hansen, T. R. 1999. Pregnancy-specific protein $B$ induces release of an alpha chemokine in bovine endometrium. Endocrinology 140:542-545.

Ayalon, N. 1978. A review of embryonic mortality in cattle. J. Reprod. Fertil. 54:483493.

Baetz, A. L, Barnett, D., Bryner, J. H., and Cysewski, S. J. 1980. Plasma progesterone concentration in the bovine before abortion or parturition in animals exposed to Sarcocystis cruze, Campylobacter fetus, or Aspergillus. Am . J. Vet. Res. 41:17671768. 
Baetz, A. L., Leiting, S. E., Bryner, J., and Barnett, D. 1981. Prepartum changes of plasma concentrations of prostaglandin $\mathrm{F}$ and 13, 14-ketoprostaglandin metabolites in pregnant animals exposed to Sarcocystis Campylobacter fetus. Am. J. Vet. Res. 42:2224.

Bartol, F. F., Roberts, R. M., Bazer, F. W., Lewis, G. S., Godkin, J. D., and Thatcher, W. W. 1985. Characterization of proteins produced in vitro by peri-attachment bovine conceptuses. Biol. Reprod. 32:681-694.

Beal, W. E., Short, R. E., Staigmiller, R. B., Bellows. R. A., Kaltenbach, C. C., and Dunn, T. G. 1978. Influence of dietary energy intake on bovine pituitary and luteal function. J. Anim. Sci. 46:181-188.

Betteridge, K. J., Randall, G. C. B., Eaglesome, M. D., and Sugden, E. A. 1984. The influence of pregnancy of $\mathrm{PGF}_{2 \alpha}$ secretion in cattle. I, Concentrations of 15-keto-13,14dihydro-prostaglandin $\mathrm{F}_{2 \alpha}$ and progesterone in peripheral blood of recipients of transferred embryos. Anim. Reprod. Sci. 7:195-216.

Bianca, W. 1985. Reviews of the progress of dairy science. Section A. Physiology. Cattle in a hot environment. J. Dairy Res. 32:291-339.

Bielanski, A. and Dubuc, C. 1995. In vitro fertilization of ova from cows experimentally infected with a non-cytopathic strain of bovine viral diarrhea virus. Anim. Reprod. Sci. 38:215-221.

Bishop, M. W. H. 1964. A paternal contribution to embryonic death. J. Reprod. Fertil. 7:383-396.

Biggers, B. G., Geisert, R. D., Wettemann, R. P., and Buchanan, D. S. Effect of heat stress on early embryonic development in the beef cow. J. Anim. Sci. 64:1512-1518.

Bossis, I., Wettemann, R. P., Welty, S. D., Vizcarra, J. A., Spicer, L. J., and Diskin, M. G. 1999. Nutritionally induced anovulation in beef heifers: ovarian and endocrine function preceding cessation of ovulation. J. Anim. Sci. 77:1536-1546.

Boyd, H., Bacsich, P., Young, A., and McCracken, J. A. 1969. Fertilization and embryonic survival in dairy cattle. Br. Vet. J. 125:87-96.

Breuel, K. F., Lewis, P. E., Inskeep, E. K., and Butcher, R. L. 1993. Endocrine profiles and follicular development in early-weaned postpartum beef cows. J. Reprod. Fertil. 97:205-212.

Bruce, H. M. 1961. Time relations in the pregnancy-block induced in mice by strange males. J. Reprod. Fertil. 2:138-142. 
Bulman, D. C. and Lamming, G. E. 1979. The use of milk progesterone analysis in the study of oestrus detection, herd fertility and embryonic mortality in dairy cattle. Br. Vet. J. 135:559-567.

Burgoyne, P. S., Holland, K., and Stephens, R. 1991. Incidence of numerical chromosome anomalies in human pregnancy estimation from induced and spontaneous abortion data. Hum. Reprod. 6:555-565.

Butcher, R. L., Blue, J. D., and Fugo, N. W. 1969. Role of the intrauterine environment on ova after normal and delayed ovulation. Biol. Reprod. 1:149-151.

Butcher, R .L. and Fugo, N. W. 1967. Overripeness and the mammalian ova. II. Delayed ovulation and chromosomal anomalies. Fert. Steril. 18:297-302.

Butcher, R. L. and Pope, R. S. 1979. Role of estrogen during prolonged estrous cycles of the rat on subsequent embryonic death or development. Biol. Reprod. 21:491-495.

Butcher, R. L., Reber, J. E., Lishman, A. W., Breuel, K. F., Schrick, F. N., Spitzer, J. C., and Inskeep, E. K. 1992. Maintenance of pregnancy in postpartum beef cows having short-lived corpora lutea. J. Anim. Sci. 70:3831-3837.

Butler, W. R. 1998. Effect of protein nutrition on ovarian and uterine physiology in dairy cattle. J. Dairy Sci. 81:2533-2539.

Butler, W. R. 2000. Nutritional interactions with reproductive performance in dairy cattle. Anim. Reprod. Sci. 60-61:449-457.

Cartmill J. A., El-Zarkouny, S. Z., Hensley, B. A., Lamb, G. C., and Stevenson, J. S. 2000. Stage of cycle, incidence and timing of ovulation, and pregnancy rates in dairy cattle after three timed breeding protocols. J. Anim. Sci. 78:216 (Abst.).

Cavestany, D., El-Whishy, A. B., and Foote, R. H. 1985. Effect of season and high environmental temperature on fertility of Holstein cattle. J. Dairy Sci. 68:1471-1478.

Chang, M. C. 1952. Development of bovine blastocyst with a note on implantation. Anat. Rec. 113:143-162.

Coleman, D. A., Dailey, R. E., Leffel, R. E., and Baker, R. D. 1987. Estrous synchronization and establishment of pregnancy in bovine embryo transfer recipients. J. Dairy Sci. 70:858-866.

Cooper, D. A., Carver, D. A., Villeneuve, P., Silvia, W. J., and Inskeep, E. K. 1991. Effects of progestogen treatment on concentrations of prostaglandins and oxytocin in plasma from the posterior vena cava of postpartum beef cows. J. Reprod. Fertil. 91:411-421. 
Crossley, P. H. Martinez, S., and Martin, G. R. 1996. Midbrain development induced by FGF8 in the chick embryo. Nature 380:66-68.

Curran, S., Pierson, M. S., and Ginther, O. J. 1986. Ultrasonographic appearance of the bovine conceptus from days 20 through 60. J. Am. Vet. Med. Assn. 189:12951302.

Cushman, R. A., Hedgpeth, V. S., Echternkamp, S. E., and Britt, J. H. 2000.

Evaluation of numbers of microscopic and macroscopic follicles in cattle selected for twinning. J. Anim. Sci. 78:1564-1567.

DeJarnette, J. M., Saacke, R. G., Bame, J. H., and Vogler, C. J. 1992. Accessory sperm: their importance to fertility and embryo quality, and attempts to alter their numbers in artificially inseminated cattle. J. Anim. Sci. 70:484-491.

Del Vecchio, R. P., Sasser, R. G., and Randel, R. D. 1990. Effect of pregnancyspecific protein B on prostaglandin F2 alpha and prostaglandin E2 release by day 16perifused bovine endometrial tissue. Prostaglandins 40:271-282.

Del Vecchio, R. P., Sutherland, W. D., and Sasser, R. G., 1995. Effect of pregnancyspecific protein $B$ on luteal cell progesterone, prostaglandin and oxytocin production during two stages of the bovine estrous cycle. J. Anim. Sci. 73:2662-2668.

Del Vecchio, R. P., Sutherland, W. D., and Sasser, R. G. 1995. Prostaglandin F2 alpha, progesterone and oxytocin production by cultured bovine luteal cells treated with prostaglandin E2 and pregnancy-specific protein B. Prostaglandins 50:137-150.

Del Vecchio, R. P., Sutherland, W. D., and Sasser, R. G. 1996. Bovine luteal cell production in vitro of prostaglandin $\mathrm{E} 2$, oxytocin and progesterone in response to pregnancy-specific protein B and prostaglandin alpha. J. Reprod. Fertil. 107:131-136.

Demmers K. J., Derecka, K., and Flint, A. 2001. Trophoblast interferon and pregnancy. Reproduction 121:41-49.

Diskin, M. G. and Niswender, G. D. 1989. Effect of progesterone supplementation on pregnancy and embryo survival in ewes. J. Anim. Sci. 67:1559-1563.

Diskin, M. G. and Sreenan, J. M. 1980. Fertilization and embryonic mortality rates in beef heifers after artificial insemination. J. Reprod. Fertil. 59:463-468.

Donaldson, L. E., Bassett, J. M., and Thorburn, G. D. 1970. Peripheral plasma progesterone concentration of cows during puberty, oestrous cycles, pregnancy and lactation, and the effects of under-nutrition or exogenous oxytocin on progesterone concentration. J. Endo 48:599-614. 
Dunlap, S. E. and Vincent, C. K. 1971. Influence of postbreeding thermal stress on conception rate in beef cattle. J. Anim. Sci. 32:1216-1218.

Dunne, L. D., Diskin, M. G., and Sreenan, J. M. 2000. Embryo and foetal loss in beef heifers between day 14 of gestation and full term. Anim. Reprod. Sci. 58:39-44.

Ealy, A. D., Larson, S. F., Liu, L., Alexenko, A. P., Winkelman, G. L., Kubisch, H. M., Bixby, J. A., and Roberts, R. M. 2001. Polymorphic forms of expressed bovine interferon- $\tau$ genes: Relative transcript abundance during early placental development, promoter sequences of genes and biological activity of protein products. Endocrinology 142:2906-2915.

Echternkamp, S. E. 1987. Fetal development in cows with multiple fetuses. Theriogenology 27:226 (Abst.).

Echternkamp, S. E. 1992. Fetal development in cattle with multiple ovulations. J. Anim. Sci. 70:2309-2321.

Echternkamp, S. E. and Gregory, K. E. 1999. Effects of twinning on postpartum reproductive performance in cattle selected for twin births. J. Anim. Sci. 77:48-60.

Echternkamp, S. E., Gregory, K. E., Dickerson, G. E., Cundiff, L. V., Koch, R. M., and Van Vleck, L. D. 1990. Twinning in cattle: II. Genetic and environmental effects on ovulation rate in puberal heifers and postpartum cows and the effects of ovulation rate on embryonic survival. J. Anim. Sci. 68:1877.

Eckblad, W. P., Sasser, R. G., Ruder, C. A., Panlasgui, P., and Kuczynski, T. 1985. Localization of pregnancy specific protein $B$ (PSPB) in bovine placental cells using a glucose oxidase-anti-glucose oxidase immunohistochemical stain. J. Anim. Sci 61 (Supp):149-150 (Abst.).

Eid, L. N., Lorton, S. P., and Parrish, J. J. 1994. Paternal influence on S-phase in the first cell cycle of the bovine embryo. Biol. Reprod. 51:1232-1237.

Eley, R. M., Thatcher, W. W., and Bazer, F. W. 1979. Hormonal and physical changes associated with bovine conceptus development. J. Reprod. Fertil. 55:181-190.

Eley, R. M., Thatcher, W. W., Bazer, F. W., Wilcox, C. J., Becher, R. B., Head, H. H., and Adkinson, R. W. 1978. Development of the conceptus in the bovine. J. Dairy Sci. 61:467-473.

El-Zarkouny, S. Z., Cartmill, J. A., Hensley, B. A., and Stevenson, J. S. 2000. Progesterone increases pregnancy rates and embryo survival in lactating dairy cows. J. Dairy Sci. 83:217 (Abst.). 
Erb, R. E., Estergreen, V. L., Gomes, W. R., Plotka, E. D., and Frost, O. L. 1968. Progestin levels in corpora lutea and progesterone in ovarian venous and jugular vein blood plasma of the pregnant bovine. J. Dairy Sci 51:401-410.

Evans, C. A. and Kennedy, T. G. 1978. The importance of prostaglandin synthesis for the initiation of blastocyst implantation in the hamster. J. Reprod. Fertil. 54:255-261.

Farin, C. E., Imkawa, K., Hansen, T. R., McDonnell, J. J., Murphy, C. N., Farin, P. W., and Roberts, R. M. 1990. Expression of trophoblastic interferon genes in sheep and cattle. Biol. Reprod. 43:210-218.

Fray, M. D., Paton, D. J., and Alenius, S. 2000. The effects of bovine viral diarrhoea virus on cattle reproduction in relation to disease control. Anim. Reprod. Sci. 6061:615-627.

Fricke, P. M. and Wiltbank, M. C. 1999. Effect of milk production on the incidence of double ovulation in dairy cows. Theriogenology 52:1133-1143.

Fugo, N. W. and Butcher, R. L. 1966. Overripeness and the mammalian ova. I. Overripeness and early embryonic development. Fert. Steril. 17:804-814.

Fugo, N. W. and Butcher, R. L. 1971. Effects of prolonged estrous cycles on reproduction in aged rats. Fert. Steril. 22:98-101.

Gandolfi, F. 1994. Autocrine, paracrine and environmental factors influencing embryonic development from zygote to blastocyst. Theriogenology 41:95-100.

Garrett, J. E., Geisert, R. D., Zavy, M. T., and Morgan, G. L. 1988. Evidence for maternal regulation of early conceptus growth and development in beef cattle. J. Reprod. Fertil. 84:437-446.

Ginther, O. J. 1984. Postfixation embryo reduction in unilateral and bilateral twins in mares. Theriogenology 22:213-220.

Ginther, O. J., Bergfelt, D. R., Beg, M. A., and Kot K. 2001. Follicle selection in cattle: Relationships among growth rate, diameter ranking, and capacity for dominance. Biol. Reprod. 65:345-350.

Ginther, O. J. and Pierson, R. A. 1984. Ultrasonic anatomy and pathology of the equine uterus. Theriogenology 21:505-

Gombe, S. and Hansel, W. 1973. Plasma luteinizing hormone (LH) and progesterone levels in heifers on restricted energy intakes. J. Anim. Sci. 37:728-733. 
Grooms, D. L., Brock, K. V, Pate, J. L., and Day, M. L. 1998. Changes in ovarian follicles following acute infection with bovine viral diarrhea virus. Theriogenology 49:595-605.

Gross, T. S., Plante, C., Thatcher, W. W., Hansen, P. J., Helmer, S. D., and Putney, D. J. 1988. Secretory proteins of the bovine conceptus alter endometrial prostaglandin and protein secretion in vitro. Biol. Reprod. 39:977-987.

Hanrahan, J. P. 1983. The inter-ovarian distribution of twin ovulations and embryo survival in the bovine. Theriogenology 20:3.

Hansen, T. R., Austin, K. J., Perry D. J., Pru, J. K., Texeira, M. G., and Johnson, G. A. 1999. Mechanisms of action of interferon-tau in the uterus during early pregnancy. J. Reprod. Fertil. (Supp) 54: 329-339.

Hockett, M. E., Hopkins, F. M., Lewis, M. J., Saxton, A. M., Dowlen, H. H., Oliver, S. P., and Schrick, F. N. 2000. Endocrine profiles following experimentally-induced clinical mastitis in Jersey cows. Anim. Reprod. Sci. 58:241-251.

Hockett, M. E., Rohrbach, N. R., and Schrick, F. N. 1998. Effect of administration of $\mathrm{PGF}_{2 \alpha}$ on embryonic development and quality in cows supplemented with exogenous progestogen. J. Anim. Sci. 76 (Suppl 1):241 (Abst.).

Houe, H. 1999. Supervisorship of animals persistently infected with bovine viral diarrhoea virus (BVDV) infections. Vet. Microbiol. 64:89-107.

Howard, J. G., Donaghue, A. M., Johnston, L. A., and Wildt, D. E. 1993. Zona pellucida filtration of structurally abnormal spermatozoa and reduced fertilization in teratospermic cats. Biol. Reprod. 49:131-139.

Howarth, B. Jr., Allison, C. W., and Ulberg, L. C. 1965. Importance of uterine environment on rabbit sperm prior to fertilization. J. Anim. Sci. 24:1027-1032.

Humblot, P., Camous, S., Martal, J., Jeanguyot, N., Thibier, M., and Sasser, R. G. 1988. Pregnancy-specific protein $B$, progesterone concentrations and embryonic mortality during early pregnancy in dairy cows. J. Reprod. Fertil. 83:215-223.

Humblot, P., De Montigny, G., Jeanguyot, N., Tetedoie, F., Payen, B., Thibier, M., and Sasser, R. G. 1990. Pregnancy-specific protein B and progesterone concentrations in French Alp goats throughout gestation. J. Reprod. Fertil. 89:205-212.

Huntington, G. B. 1990. Energy metabolism in the digestive tract and liver of cattle: influence of physiological state and nutrition. Reprod. Nutr. Dev. 30:35-47. 
Inskeep, E. K. 2002. Factors that affect embryonic survival in the cow: Application of technology to improve calf crop. In Factors Affecting Calf Crop: Biotechnology of Reproduction. Edited by Michael J. Fields, Robert S. Sand, and Joel Y. Yelich. CRC Press, Boca Raton FL. Chapter 19. p 255-275.

Johansson, I. 1932. The sex ratio and multiple births in cattle. Zeitschr. Zuchtung. B. 24:183.

Joubert, D. M. 1952. Twin births among cattle in South Africa. Farming in South Africa Jan 1952. 9-14.

Kastelic J. P. 1994. Noninfectious embryonic loss in cattle. Vet. Med. 584-589.

Kastelic, J. P., Curran, S., Pierson, R. A., and Ginther, O. J. 1988. Ultrasonic evaluation of the bovine conceptus. Theriogenology 29:39-54.

Kastelic, J. P. and Ginther, O. J. 1989. Fate of conceptus and corpus luteum after induced embryonic loss in heifers. JAVMA 194:922-928.

Kastelic, J. P., Northey, D. L., and Ginther, O. J. 1991. Spontaneous embryonic death on days 20 to 40 in heifers. Theriogenology 35:351-363.

Kennedy, T. G. 1977. Evidence for a role for prostaglandins in the initiation of blastocyst implantation in the rat. Biol. Reprod. 16:286-291.

Kerbler, T. L., Buhr, M. M., Jordan, L. T., Leslie, K. E., and Walton, J. S. 1997. Relationship between maternal plasma progesterone concentrations and interferon-tau synthesis by the conceptus in cattle. Theriogenology 47:703-714.

Kidder, H. E., Black, W. G., Wiltbank, J. N., Ulberg, L. L., and Casida, L. E. 1954. Fertilization rates and embryonic death rates in cows bred to bulls of different levels of fertility. J. Dairy Sci. 37:691-697.

Kindahl H., Edqvist, L. E., Bane, A., and Granstrom, E. 1976. Blood levels of progesterone and 15-keto-13,14-dihydro-prostaglandin $\mathrm{F}_{2 \alpha}$ during the normal oestrous cycle and early pregnancy in heifers. Acta. Endocr. Copenh. 82:134-149.

King, W. A. 1990. Chromosome abnormalities and pregnancy failure in domestic animals. In Advances in Veterinary Science and Comparative Medicine Vol. 34 Domestic Animal Cytogenetics. Ed RA McFeely, Academic Press, San Diego. 229250.

King, W. A. 1991. Embryo-mediated pregnancy failure in cattle. Can. Vet. J. 32:99103. 
King, G. J. and Atkinson, B. A. 1987. The bovine intercaruncular placenta throughout gestation. An. Reprod. Sci. 12:241-254.

King, G. J., Atkinson, B . A., and Robertson, H. A. 1979. Development of the bovine placentome during the second month of gestation. J. Reprod. Fertil. 55:173-180.

King, G. J., Atkinson, B. A., and Robertson, H. A. 1980. Development of the bovine placentome from days 20 to 29 of gestation. J. Reprod. Fertil. 59:95-100.

King, W. A., Guay, P., and Picard L. 1987. A cytogenetical study of 7-day-old bovine embryos of poor quality. Genome 29:160-164.

Kinsel, M. L., Marsh, W. E., Ruegg, P. L., and Etherington, W. G. 1998. Risk factors for twinning in dairy cows. J. Dairy Sci. 81:989-993.

Knickerbocker, J. J., Thatcher, W. W., Bazer, F. W. Drost, M., Barron, D. H., Fincher, K. B., and Roberts, R. M. 1986. Proteins secreted by day 16 and 18 conceptuses extend corpus luteum function in cows. J. Reprod. Fertil. 77:381-391.

Kummerfield, H. L., Oltenacu, A. B., and Foote, R. H. 1978. Embryonic mortality in dairy cows estimated by nonreturns to service, estrus, and cyclic milk progesterone patterns. J. Dairy Sci. 61:1773-1777.

Lafrance, M. and Goff, A. K. 1985. Effect of pregnancy on oxytocin-induced release of prostaglandin $F_{2 \alpha}$ in heifers. Biol. Reprod. 33:1113-1119.

Lee, C. N., Maurice, E., Ax, R. L., Pennington, J. A., Hoffman, W. F., and Brown, M. D. 1983. Efficacy of gonadotropin-releasing hormone administered at the time of artificial insemination of heifers and postpartum and repeat breeder dairy cows. Am. J. Vet. Res. 44:2160-2163.

Lewis, G. S., Caldwell, D. W., Rexroad, C. E. Jr. 1990. Effects of gonadotropinreleasing hormone and human chorionic gonadotropin on pregnancy rate in dairy cattle. J. Dairy Sci. 73:66-72.

Lopez-Gatius, F., Santolaria, P., Yaniz, J., Rutllant, J., and Lopez-Bejar, M. 2002. Factors affecting pregnancy loss from gestation day 38 to 90 in lactating dairy cows from a single herd. Theriogenology 57:1251-1261.

Lucy, M. C. and Stevenson, J. S. 1986. Gonadotropin-releasing hormone at estrus: luteinizing hormone, estradiol, and progesterone during the periestrual and postinsemination periods in dairy cattle. Biol. Reprod. 35:300-311.

Macmillan, K. L., Lean, I. J., and Westwood, C. T. 1996. The effects of lactation on the fertility of dairy cows. Aust. Vet. J. 73:141-147. 
Malayer, J. R., Hansen, P. J., Gross, T. S., and Thacher, W. W. 1990. Regulation of heat shock-induced alterations in the release of prostaglandins by the uterine endometrium of cows. Theriogenology 34:219-230.

Mann, G. E. and Lamming, G. E. 2001. Relationship between maternal endocrine environment, early embryo development and inhibition of the luteolytic mechanism in cows. Reproduction 121:175-180.

Mann, G. E., Lamming, G. E., Robinson, R. S., and Wathes, D. C. 1999. The regulation of interferon- $\tau$ production and uterine hormone receptors during early pregnancy. J. Reprod. Fertil. Suppl. 54:317-328.

Marion, G. B. and Gier, H. T. 1958. The process of placentation in the bovine. J. Anim. Sci. 17:1216-1217 (Abst.).

Maurer, R. R. and Chenault, J. R. 1983. Fertilization failure and embryonic mortality in parous and nonporous beef cattle. J. of Anim. Sci. 56:1186-1189.

Maurer, R. R. and Echternkamp, S. E. 1982. Hormonal asynchrony and embryonic development. Theriogenology 17:11-22.

Mawhinney S. and Roche, J. F. 1978. Factors involved in oestrous cycle control in the bovine. In Control of Reproduction in the Cow. Edited by J. M. Sreenan. EEC, Luxenbourg. P 511-530.

McCausland, I. P., Slee, K. J., and Hirst, F. S. 1987. Mycotic abortion in cattle. Aust. Vet. J. 64:129-132.

McDonald, L. M., Nichols, R. E., and McNutt, S. H. 1952. Studies on corpus luteum ablation and progesterone replacement therapy during pregnancy in the cow. Am. J. Vet. Res. 13:446-451.

Mee, M. O., Stevenson, J. S., Alexander, B. M., and Sasser. R. G. 1993. Administration of $\mathrm{GnRH}$ at estrus influences pregnancy rates, serum concentrations of $\mathrm{LH}, \mathrm{FSH}$, estadiol-17 beta, pregnancy-specific protein B, progesterone, proportion of luteal cell types, and in vitro production of progesterone in dairy cattle. J. Anim. Sci. 71:185-198.

Melton, A. A., Berry, R. O., and Butler, O. D. 1951. The interval between the time of ovulation and attachment of the bovine embryo. J. Anim. Sci. 10:993-1005.

Meyling, A. and Jensen, A. M. 1988. Transmission of bovine viral diarrhoea virus (BVDV) by artificial insemination (Al) with semen from a persistently-infected bull. Vet. Microbiol. 17:97-105. 
Mihm, M., Baguishi, A., Boland, M. P., and Roche, J. F. 1994. Association between the duration of dominance of the ovulatory follicle and pregnancy rate in beef heifers. J. Reprod. Fertil. 102:123-130.

Miller, D., Hrudka, M., Cates, W. F., and Mapletoft, R. 1982. Infertility is a bull with nuclear sperm defect: a case report. Theriogenology 17:611-621.

Miller, J. M. and Van der Maaten, M. J. 1986. Experimentally induced infectious bovine rhinotracheitis virus infection during early pregnancy: effect on the bovine corpus luteum and conceptus. Am. J. Vet. Res. 47:223-228.

Miller, J. M. and Van der Maaten, M. J. 1987. Early embryonic death in heifers after inoculation with bovine herpesvirus-1 and reactivation of latent virus in reproductive tissues. Am. J. Vet. Res. 48:1555-1558.

Miller, J. M., Van der Maaten, M. J., and Whetstone, C. A. 1989. Infertility in heifers inoculated with modified-live bovine herpesvirus- 1 vaccinal strains against infectious bovine rhinotracheitis on postbreeding day 14. Am. J. Vet. Res. 50:551-554.

Moor, M. R. and Rowson, L. E. A. 1966. Local uterine mechanisms affecting luteal function in the sheep. J. Reprod. Fertil. 11:307.

Morris, L. M., Gonzalez-Padilla, E., Niswender, G. D., and Wiltbank, J. N. 1976. Peripheral progesterone levels in pregnant and non-pregnant heifers following use of hCG. Theriogenology 6:367-373.

Nadir, S., Saacke, R. G., Bame, J. H., Mullins, J., and Degelos, S. 1993. Effect of freezing semen and dosage of sperm on number of accessory sperm, fertility and embryo quality in artificially inseminated cattle. J. Anim. Sci. 71:199-204.

Nephew, K. P., McClure K. E., Ott, T. L., Bubois, D. H., Bazer. F. W., and Pope, W. F. 1991. Relationship between variation in conceptus development and differences in estrous cycle duration in ewes. Biol. Reprod. 44:536-539.

Northey, D. L. and French, L. R. 1980. Effect of embryo removal and intrauterine infusion of embryonic homogenates on the lifespan of the bovine corpus luteum. J. Anim. Sci. 59:298-302.

Novaro, V., Rettori, V., Gonzalez, E. T., Jawerbaum, A., Faletti, A., Canteros, G., and de Gimeno, M. A. 1996. Interaction between uterine PGE and $\mathrm{PGF}_{2 \alpha}$ production and the nitridergic system during embryonic implantation in the rat. Prostaglandins 51:363376.

Oppenheim, J. J., Zachariae, C. O. C., Mukaida, N., and Matsushima, K. 1991. Properties of the novel proinflammatory supergene "intercrine" cytokine family. Ann. Rev. Immun. 9:617-648. 
Ostermeier, G. C., Sargeant, G. A., Yandell, B. S., Evenson, D. P., and Parrish, J. J. 2001. Relationship of bull fertility to sperm nuclear shape. J. Androl. 22:595-603.

Oussaid, B., Mariana, J. C., Poulin, N., Fontaine, J., Lonergan, P., Beckers, J. F., and Congie, Y. 1999. Reduction of the developmental competence of sheep oocytes by inhibition of LH pulses during the follicular phase with a $\mathrm{GnRH}$ antagonist. J. Reprod. Fertil. 117:71-77.

Page R. D., Kirkpatrick-Keller, D., and Butcher, R. L. 1983. Role of age and length of the estrous cycle in alteration of the oocyte and intrauterine environment in the rat. J. Reprod. Fert. 69:23-28.

Paton, D. J., Christiansen, K. H., Alenius, S., Cranwell, M. P., Pritchard, G. C., and Drew, T. W. 1998. Prevalence of antibodies to bovine viral diarrhoea virus and other viruses in bulk tank milk in England and Wales. Vet. Rec. 142:385-391.

Phatak, A. P., Whitmore, H. L., and Brown M. D. 1986. Effect of gonadotropinreleasing hormone on conception rate of repeat-breeder dairy cattle. Theriogenology 26: 605 .

Pope, G. S., Gupta, S. K. and Munro, I. B. 1969. Progesterone levels in the systemic plasma of pregnant, cycling and ovariectomized cows. J. Reprod. Fertil. 20:369-381.

Pope, W. F., Maurer, R. R., and Stormshak, F. 1982. Distribution of progesterone in the uterus, broad ligament, and uterine arteries of beef cows. Anat. Rec. 203:245-250.

Pratt, B. R., Butcher, R. L., and Inskeep, E. K. 1977. Antiluteolytic effect of the conceptus and $\mathrm{PGE}_{2}$ in ewes. J. Anim. Sci. 46:784-791.

Pru, J. K., Rueda, B. R., Austin, K. J., Thatcher, W. W., Guzeloglu, A., and Hansen, T. R. 2001. Interferon-tau suppresses prostaglandin F2alpha secretion independently of the mitogen-activated protein kinase and nuclear factor kappa B pathways. Biol. Reprod. 64:965-973.

Pursley, J. R., Mee, M. O., and Wiltbank, M. C. 1995. Synchronization of ovulation in dairy cows using $\mathrm{PGF}_{2 \alpha}$ and $\mathrm{GnRH}$. Theriogenology 44:915-923.

Putney, D. J., Drost, M., and Thatcher, W. W. 1988a. Embryonic development in superovulated dairy cattle exposed to elevated ambient temperatures between days 1 to 7 post insemination. Theriogenology 30:195-209.

Putney, D. J., Malayer, J. R., Gross. T. S., Thatcher, W. W., Hansen, P. J., and Drost, M. 1988b. Heat stress-induced alterations in the synthesis and secretion of proteins and prostaglandins by cultured bovine conceptuses and uterine endometrium. Biol. Reprod. 39:717-728. 
Rabiee, A. R., Macmillan, K. L., and Schwarzenberger, F. 2000. Effect of level of feed intake on plasma progesterone concentrations in desolrelin-implanted dairy cows treated with a CIDR device. J. Anim. Sci. 78(Suppl. 1):221 (Abst.).

Ramirez-Godinez, J. A., Kiracofe, G. H., McKee, R. M., Schalles, R. R., and Kittok, R. J. 1981. Reducing the incidence of short estrous cycles in beef cows with norgestomet. Theriogenology 15:613-623.

Rankin, J. C., Ledord, B. E., Jonsson, H. T. Jr., and Baggett, B. 1979. Prostaglandins, indomethacin, and the decidual cell reaction in the mouse uterus. Biol. Reprod. 20:399404.

Rettmer, I., Stevenson, J. S., Corah, L. R. 1992. Endocrine responses and ovarian changes in inseminated dairy heifers after an injection of $\mathrm{GnRH}$ agonist 11-13 days after estrus. J. Anim. Sci. 70:508-517.

Roberts, S. J. 1986. In Veterinary Obstetrics and Genital Diseases. Second edn. Woodstock. Ithaca, NY. p 100.

Roche, J. F., Mackey, D., and Diskin, M. D. 2000. Reproductive management of postpartum cows. Anim. Reprod. Sci. 60-61:703-712.

Royal, M. D., Darwash, A. O., Flint, A. P. F., Webb, R., Wolliams, J. A., and Lamming, G. E. 2000. Declining fertility in dairy cattle: Changes in traditional and endocrine parameters of fertility. Anim. Sci. 70:487-502.

Saacke, R. G., Dalton, J. C., Nadir, S., Nebel, R. L., and Bame, J. H. 2000.

Relationship of seminal traits and insemination time to fertilization rate and embryo quality. Anim. Reprod. Sci. 60-61:663-677.

SAS. SAS User's Guide: Statistics (Version 5) Cary NC: SAS Institute Inc. 1985.

Sasser, R. G., Ruder, C. A., Ivani, K. A., Butler, J. E., and Hamilton, W. C. 1986. Detection of pregnancy by radioimmunoassay of a novel pregnancy-specific protein in serum of cows and a profile of serum concentrations during gestation. Biol. Reprod. 35:933-942.

Schallenberger, E., Echams, D., and Meyer, H. H. D. 1989. Sequences of pituitary, ovarian and uttering hormone secretion during the first 5 weeks of pregnancy in dairy cattle. J. Reprod. Fertil. 37(Suppl.):269-276.

Schrick, F. N., Inskeep, E. K., and Butcher, R. L. 1993. Survival of embryos from early postpartum beef cows in normally cycling recipients. Biol. Reprod. 49:617-621. 
Seals, R. C., Matamoros, I., and Lewis, G. S. 2002. Relationship between postpartum changes in 13,14-dihydro-15-keto-PGF2 $\alpha$ concentrations in Holstein cows and their susceptibility to endometritis. J. Anim. Sci. 80:1068-1073.

Semambo, D. K., Ayliffe, T. R., Boyd, J. S., and Taylor, D. J. 1991. Early abortion in cattle induced by experimental intrauterine infection with Actinomyces pyogenes. Vet. Rec. 129:12-16.

Semambo, D. K., Eckersall, P. D., Sasser, R. G., and Ayliffe, T. R. 1992. Pregnancy specific protein $B$ and progesterone in monitoring viability of the embryo in early pregnancy in the cow after experimental infection with actinomyces pyogenes. Theriogenology 37:741-748.

Sheffel, C. E., Pratt, B. R., Ferrell, W. L., and Inskeep, E. K. 1982. Induced corpora lutea in the postpartum beef cow II: effects of treatment with progesterone and gonadotrophins. J. Anim. Sci. 54:830-36.

Shelton, M. 1964. Relation of environmental temperature during gestation to birth weight and mortality in lambs. J. Anim. Sci. 23:360-365.

Silva, P. J., Juengel, J. L., Rollyson, M. K., and Niswender, G. D. 2000. Prostaglandin metabolism in the ovine corpus luteum: catabolism of prostaglandin $F(2 a l p h a)$ (PGF(2alpha)) coincides with resistance of the corpus luteum to PGF(2alpha). Biol. Reprod. 63:1229-12236.

Silvia, W. J. 1998. Changes in reproductive performance of Holstein dairy cows in Kentucky from 1972 to 1996. J. Dairy Sci. 81(Suppl. 1):244 (Abst.).

Silvia, W. J., Raw, R. E., Aldrich, S. L., and Hayes, S. H. 1992. Uterine secretion of prostaglandin $\mathrm{F}_{2 \alpha}$ in response to oxytocin in ewes: changes during the estrous cycle and early pregnancy. Biol. Reprod. 46:1007-1015.

Smith, P. C., Nusbaum, K. E., Kwapien, R. P. Stringfellow, D. A., and Driggers, K. 1990. Necrotic oophoritis in heifers vaccinated intravenously with infectious bovine rhinotracheitis virus vaccine during estrus. Am. J. Vet. Res. 51:969-972.

Soede, N. M., Helmond, F. A., and Kemp, B. 1994. Periovulatory profiles of oestradiol, $\mathrm{LH}$ and progesterone in relation to oestrus and embryo mortality in multiparous sows using transrectal ultrasonography to detect ovulation. J. Reprod. Fertil. 101:633-641.

Stevenson, J. S., Call, E. P., Scoby, R. K., and Phatak, A. P. 1990. Doubleinsemination and gonadotropin-releasing hormone treatment of repeat-breeding dairy cattle. J. Dairy Sci. 73:1766-1772. 
Stevenson, J. S., Frantz, K. D., and Call, E. P. 1988. Conception rates on repeat breeders and dairy cattle with unobserved estrus after prostaglandin F2 $\alpha$ and gonadotropin-releasing hormone. Theriogenology 29:451.

Stevenson, J. S., Phatak , A. P., Rettmer, I., and Stewart, R. E. 1993.

Postinsemination administration of receptal: follicular dynamics, duration of cycle, hormonal responses and pregnancy rates. J. Dairy Sci. 76:2536-2547.

Stevenson, J. S., Schmidt, M. K., and Call, E. P. 1983. Factors affecting reproductive performance of dairy cows first inseminated after five weeks postpartum. J. Dairy Sci. 66:1148-1154.

Stevenson, J. S., Schmidt, M. K., and Call, E. P. 1984. Gonadotropin-releasing hormone and conception in Holsteins. J. Dairy Sci. 67: 140-145.

Tanabe, T. Y. 1966. Essentiality of the corpus luteum for maintenance of pregnancy in dairy cows. J. Dairy Sci. 49:731 (Abst.).

Thur, B., Hilbe, M., Strasser, M., and Ehrensperger, F. 1997. Immunohistochemical diagnosis of pestivirus infection associated with bovine abortion and perinatal death. Am. J. Vet. Res. 58:1371-1375.

Van der Maaten, M. J. and Miller, J. M. 1985. Ovarian lesions in heifers exposed to infectious bovine rhinotracheitis virus by non-genital routes on the day after breeding. Vet. Microbiol. 10:155-163.

Van der Maaten, M. J., Miller, J. M., and Whetstone, C. A. 1985. Ovarian lesions induced in heifers by intravenous inoculation with modified-live infectious bovine rhinotracheitis virus on the day after breeding. Am. J. Vet. Res. 46:1996-1999.

Van de Leemput, E. E., Vos, P. L. A. M., Hyttel, P., Van den Hurk, R., Bevers, M. M., Van der Weijden, G. C., and Dieleman, S. J. 2000. Effects of brief postponement of the preovulatory LH surge on ovulation rates and embryo formation in eCG/prostaglandintreated heifers. Theriogenology 55:573-592.

Vogt, D. W. 1968. Sex chromosome mosaicism in a swine intersex. J. Hered. 59:166.

Weems, C. W., Weems, Y. S., Lee, C. N., and Vincent, D. L. 1989. Progesterone in uterine and arterial tissue and in jugular and uterine venous plasma of sheep. Biol. Reprod. 41:1-6.

Weems, Y. S. Bridges, P. J., Vera-Avila, H. R., Randel, R. D., Sasser, R. G., and Weems, C. W. 1997. PGE1 or PGE2, not LH, regulates secretion of progesterone in vitro by the 88-90 day ovine corpus luteum of pregnancy. Prostaglandins 55:337-353. 
Weems, Y. S., Lammoglia, M. A., Vera-Avila, H. R., Randel, R. D., Sasser, R. G., and Weems. C. W. 1998. Effects of luteinizing hormone (LH), PGE2, 8-Epi-PGE1, 8-EpiPGF2 alpha trichosanthin and pregnancy specific protein $B$ (PSPB) on secretion of prostaglandin (PG) E (PGE) or F2 alpha (PGF2 alpha) in vitro by corpora lutea (CL) from nonpregnant and pregnant cows. Prostaglandins 55:359-376.

Wildman, E. E., Jones, G. M., Wagner, P. E., Boman, R. L., Trout, H. F., and Lesch, T. N. 1982. A dairy cow body condition scoring system and its relationship to selected production variables in high producing Holstein dairy cattle. J. Dairy Sci. 65:495-501.

Winters, L. M. Green, W. W., and Comstock, R. E. 1942. Prenatal development of the bovine. Minnesota Agricultural Experiment Station, Technical Bulletin 151.

Wolfenson, D., Roth, Z., and Meidan, R. 2000. Impaired reproduction in heat-stressed cattle: basic and applied aspects. Anim. Reprod. Sci. 60-61:535-547.

Wolfenson, D. Thatcher, W. W., Badinga, L., Savio J. D., Meidan, R., Lew, B. J., BrawTal, R., and Berman, A. 1995. Effect of heat stress on follicular development during the estrous cycle in lactating dairy cattle. Biol. Reprod. 52:1106-1113.

Woody, C. O. and Ulberg, L. C. 1964. Viability of one cell sheep ova as affected by high environmental temperature. J. Reprod. Fertil. 7:275-280.

Yeates, N. T. M. 1956. The effect of high air temperature on pregnancy and birth weight in Merino sheep. Australian J. Agr. Res. 7:435.

Zavy, M. T. 1994. Embryonic mortality in cattle. In Embryonic Mortality in Domestic Species. CRC Press, Boca Raton, FL. 99-140.

Zimbelman, R. G. and Smith, L. W. 1966. Maintenance of pregnancy in ovariectomized heifers with melengestrol acetate. J. Anim. Sci 25:207-211. 


\section{VITA}

\section{Melanie Jean Starbuck}

Parents....................................................... Max L. Starbuck Carol D. Starbuck

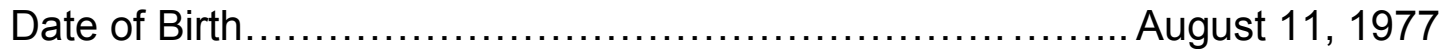

Schools Attended:

Schuyler R-1 Elementary and Middle School. $1982-1991$

Queen City, Missouri

Schuyler R-1 High School. $1991-1995$

Lancaster, Missouri

University of Missouri-Columbia..... $1995-1999$

Columbia, Missouri

West Virginia University 1999 Morgantown, West Virginia

Degrees Received:

Bachelor of Science in Animal Science..................1999

University of Missouri-Columbia, Columbia, Missouri 